Savunma Bilimleri Dergisi

The Journal of Defense Sciences

Kasim/Nov 2018, Cilt/Volume 17, Say1/Issue 2.

ISSN (Bas111) : 1303-6831 ISSN (Online): 2148-1776



\title{
Liderlik Tarzı ile Örgütsel Vatandaşlık Davranışı İlişkisi: Bir Özel Eğitim Kurumunda Uygulama
}

\author{
Mehmet KURUŞCU* ve Sefer AYDOĞAN** \\ $\ddot{O} z$
}

Bu çalışmanın amacl, yöneticinin liderlik tarzının çalışanların örgütsel vatandaşlık davranışı ile ilişkisinin belirlenmesidir. Çalışmada nicel araştırma yöntemi kullanılmıştır. Araştırmanın evreni bir özel eğitim kurumunda çalışan ögrretmenlerden oluşmaktadır. Örneklem büyüklü̈̆̈̈ 295 'tir. Araştırmada elde edilen bulgular kapsamında; dönüşümcü liderlik ile örgütsel vatandaşlık davranışı ve tüm boyutları arasında zaylf düzeyde anlamlı ve pozitif ilişki olduğu; etkileşimci liderliğin koşullu ödüllendirme boyutu ile örgütsel vatandaşlık davranışı ve sivil erdem dışındaki boyutları arasında zaylf düzeyde anlamlı ve pozitif ilişki olduğu, sivil erdem boyutu ile ise arasında anlamlı bir iliş̧ki bulunmadĭ̆ tespit edilmiştir. Bu çalışma ile, yöneticinin liderlik tarzı ve çalı̧̧anların örgütsel vatandaşlık davranışı ilişskisinin eğitim sektöründe bir özel eğitim kurumunda test edilmesi ile alanyazına katkı sağlanmaktadır. Uygulayıcılar açısından, çalışanların örgütsel vatandaşlık davranışını artırma kapsamında, en fazla katkı yapan liderlik tarzının bilinmesi sayesinde, doğru liderlik tarzını uygulamanın önemli olduğu ortaya konulmuştur.

Anahtar Kelimeler: Dönüşümcü Liderlik, Etkileşimci Liderlik, Koşullu Ödüllendirme, Liderlik Tarzı, Örgütsel Vatandaşlık Davranışı.

* Dr, Milli Savunma Üniversitesi, Hava Harp Okulu Dekanlı̆̆ı, Yönetim Bilimleri Bölümü, mkuruscu@hho.edu.tr

** Dr, Milli Savunma Üniversitesi, Hava Harp Okulu Dekanlığı, Yönetim Bilimleri Bölümü, saydogan@hho.edu.tr

Geliş Tarihi/Received:08.06.2018

Kabul Tarihi/Accepted:08.08.2018 


\title{
The Relationship Between Leadership Style and Organizational Citizenship Behavior: Research at a Private Educational Institution
}

\begin{abstract}
The aim of this study is to determine the relationship between leadership style of administrators and the organizational citizenship behavior of the employees. Quantitative research method was used in the study. The sample of the research consists of teachers who work in a private education institution. The sample size is 295. Within the findings of the research; there is a meaningful and positive relationship between the transformational leadership and organizational citizenship behavior and all dimensions at a weak level; there is a meaningful and positive relationship between conditional rewarding dimension of transactional leadership and organizational citizenship behavior except civic virtue dimension at a weak level, and there is no meaningful relationship between civic virtue dimension. This study contributes to the literature, by determination of the relationship between the leadership style and organizational citizenship behavior by tested in a special education institution in the education sector. In terms of practitioners, it has been demonstrated that it is important to implement the correct leadership style in the context of increasing organizational citizenship behavior of employees.
\end{abstract}

Keywords: Leadership Style, Organizational Citizenship Behavior, Transactional Leadership, Transformational Leadership.

\section{Giriş}

Örgütsel başarının sağlanması ve sürdürülebilmesi için çalışanların iş tanımlarında yer alan görevlerinin yanı sıra iş tanımları içinde kapsanamayan; ancak işin yapılması için gerekli olan faaliyetlerin de yerine getirilmesi için gerekli çabanın gösterilmesine ihtiyaç duyulmaktadır. Örgütün etkin ve verimli çalışması kapsamında, biçimsel rol tanımı ve resmi ödül sistemi içinde doğrudan yer almayan; fakat örgütün amaçlarının gerçekleştirilmesine katkı yapan, isteğe bağlı davranışlar olan örgütsel vatandaşlık davranışı (Organ, 1988), örgütsel başarının 
Liderlik Tarzı ile Örgütsel Vatandaşlık Davranışı İlişkisi:

Bir Özel Eğitim Kurumunda Uygulama

sağlanmasında ve sürdürülmesinde önem kazanmaktadır. Organ (1988)'ın belirlediği diğerkâmlık, centilmenlik, vicdanlılık, nezaket ve sivil erdem olan beş boyutlu sinıflandırma alanyazında en sık kullanılan sınıflandırma olarak ön plana çıkmaktadır (Özdevecioğlu, 2003).

Toplumda, örgütlerde ve gruplarda yapının üyeleri (toplumun sakinleri, çalışanlar, liderler vb.) birbirleri ile olan ilişkilerinde karşılıklı olarak ödül ve maliyet temelli bir alış veriş mantığ içinde hareket ederler. Bu alışveriş çok geniş bir yelpazede gerçekleşir, örneğin, bu alışverişin ödül ve maliyetleri; yardım etme karşılığında itibar ve saygınlık kazanma olabileceği gibi kabul edilme karşılığında bağımlılık da olabilir (Ritzer, 1996). Gouldner (1960)'ın karş111klılık normu ise bireylerin elde ettikleri ödüllere karşıllk olumlu davranış göstereceğini ileri sürmektedir. Çalışanların birbiri ile ve yöneticileri ile olan ilişkileri sosyal alışveriş kuramı çerçevesinde ele alındığında, biçimsel rol davranışlarının dışındaki davranışların karşılıklılık ilkesi kapsamında ödül ve maliyetler açısından açıklanabileceği değerlendirilmektedir (Ritzer, 1996). Sosyal alışveriş kuramı çerçevesinde, yöneticinin liderlik tarzının, sosyal alışveriş ilişkileri kapsamındaki örgütsel vatandaşlık davranışının incelenmesinde temel teşkil edebileceği değerlendirilmektedir.

Dönüşümcü ve etkileşimci liderlik davranışları örgütsel vatandaşlık davranışının açıklanmasında önemli rol oynamaktadır. Çalışanların kendilerine yönelik ilgi gösteren, destek davranışları sergileyen, kendilerini ödüllendiren, entellektüel uyarım sağlayan, katılımcı ve kendilerini cesaretlendirme yönünde algıladıkları liderlik davranışlarının, işi için zorunlu olan sorumlulukları yerine getirmenin yanı sıra, örgütün başarısı için gereken ve iş tanımı dışında kalan fazladan çabayı göstermek konusunda da çalışanları motive etmesi beklenmektedir.

Çalışanın örgütsel vatandaşlık davranışı sergilemesinde yöneticinin liderlik tarzı önemli bir öncül olarak ortaya çıkmakta ve bu iki değişken arasında bir ilişki olduğu araştırma sonuçlarında görülmektedir (Çakar ve Arbak, 2003). Yöneticinin liderlik tarzının örgütsel vatandaşlık davranışı ile ilişkisinin bilinmesi sayesinde, örgütlerde yöneticilere ne tarz liderlik uygulamalarına ağırlık vermeleri konusunda uygulayıcılara katkı sağlanacağı değerlendirilmektedir.

Örgütsel vatandaşlık davranışı ile ilgili çalışmaların geneline bakıldığında; örgütler için gerekli ve önemli olduğu tespit edildiğinden, geliştirilmesi ve özellikle 
etkili liderlik tarzları ile bu davranışların oluşturulması ve desteklenmesi önerilmektedir. Örgütsel vatandaşlık davranışında esas önemli öncül, etkili liderlik tarzının örgütlerde uygulanması olarak ortaya çıkmaktadır (Avc1, 2015; Arslantaş ve Pekdemir, 2007). Bu sebeple, çalışanların ÖVD sergilemesine katkı yapan öncüllerden biri olan lider desteği kapsamında hangi tür liderlik tarzının daha etkili olduğunun bilinmesinin uygulamada örgütsel başarıya katkı yapması ve söz konusu ilişkinin özel eğitim kurumunda test edilmesi ile alanyazına katkı sağlanması amacıyla örgütsel vatandaşlık davranışı ile liderlik tarzı ilişkisinin tespit edilmesine yönelik bir çalışma yapılmasının faydalı olacağı değerlendirilmiştir.

$\mathrm{Bu}$ çalışmada, bir bütün olarak yöneticinin liderlik tarzı kapsamında dönüşümcü liderlik ve etkileşimci liderliğin koşullu ödüllendirme davranışlarının örgütsel vatandaşlık davranışı ile ilişkisi ele alınarak hangi liderlik tarzının çalışanların örgütsel vatandaşlık davranışı sergilemesi ile daha güçlü ilişkisinin olduğunun ortaya konulması amaçlanmıştır. Bu kapsamda yapılan araştırmanın hem uygulamada hem de bu ilişkinin eğitim sektöründe bir özel eğitim kurumunda test edilmesi ile alanyazına katkı boyutunda faydalı olacağı değerlendirilmektedir.

\section{Kuramsal Çerçeve}

\section{Örgütsel Vatandaşlık Davranışı}

Yoğun rekabet koşullarında örgütün faaliyetlerini başarıyla yerine getirebilmesi için, çalışanların örgütsel vatandaşlık davranışı (ÖVD) kapsamında gönüllü olarak fazladan rol davranışı sergilemesi, çalışma arkadaşlarına yardımcı olması, örgütsel düzenlemelere uyması, örgütün amaçlarını benimsemesi, onaylamas1 ve desteklemesi beklenmektedir (Borman, 2004). ÖVD kavram olarak ilk kez Bateman ve Organ tarafından 1982 yılında Katz (1964)'ın “fazladan rol davranışı" kavramına dayalı olarak ortaya konmuştur. Yine Smith, Organ ve Near tarafindan ÖVD kavramı 1983 yılında yayımlanan ÖVD'nin yapısı ve öncüllerini konu alan makalede kullanılmıştır (Kulaklığlu, 2009; Özler, 2015; Ilie, 2014; Aslan, 2008). Katz ve Kahn'in "The Social Psychology of Organizations (Örgütlerin Sosyal Psikolojisi)" adlı eserdeki görüşleri açık sisteme dayalı örgüt modeli ve ÖVD'nin başlangıcını oluşturmakta, Peter Blau'nun mübadele yaklaşımı lider ve takipçileri arasındaki ilişkileri ele almakta; Dansereau, Graen ve Haga ise 
Liderlik Tarzı ile Örgütsel Vatandaşlık Davranışı İlişkisi:

Bir Özel Eğitim Kurumunda Uygulama

sosyal değişim kuramını yönetici-çalışan açısından ast-üst ilişkilerini ekonomik gereklilikler ve sosyal değişim kapsamında ele almaktadır (Karaslan vd., 2009).

Organ (1988) ÖVD’yi, resmi ödül sistemiyle doğrudan ilişkilendirilmeyen, iş tanımlarında belirtilen biçimsel rollerin dışında, örgüt amaçlarının gerçekleştirilmesine katkı sağlayan isteğe bağlı davranışlar olarak tanımlamaktadır. Burada, bu davranışların; biçimsel rol tanımı dışında, bireyin gönüllü olarak yaptığı ve örgütün resmi ödül sistemine doğrudan bağlı olmaması hususları üzerinde durulmaktadır. ÖVD doğrudan bireye yönelik ve örgüte yönelik davranışlar olarak iki kategoride incelenebilir. Bireye yönelik ÖVD, doğrudan örgütte yer alan bireylere yönelik ve çalışanların işle ilgili davranışlarına ilişkin; örgüte yönelik ÖVD ise örgütün görevlerinin yerine getirilmesine ilişkin konularla ilgilidir (Finkelstein ve Penner, 2004). Alanyazın incelendiğinde ÖVD tanımında üç temel kriter öne çıkmakta olup bunlar (Avc1, 2015); isteğe bağlı ve gönüllülük esaslı olması, resmi görev tanımlarında/resmi ödül sisteminde yer almayan rol fazlası davranışlar olması ve örgütsel etkililik ile başarıya katkı sağlamasıdır. ÖVD tanımında geçen gönüllülük kavramıyla, çalışanın örgütteki rolü veya biçimsel görev tanımında yer almayan zorunlu davranışlardan olmadığı ifade edilmektedir (İşbaş1, 2000). George ve Brief (1992) ise, ÖVD’yi; çalışanların biçimsel rol davranışlarının içinde veya üzerinde olan fakat resmi ödül sisteminin dışında yer alan davranışlar olarak tanımlamaktadır. Yani, söz konusu davranışların resmi ödül sistemi ile doğrudan bir ilişkisi olmaması, örgüt amaçlarına katkı sağlaması ve isteğe bağlı olması ÖVD kriteri olarak öne çıkmaktadır. Schnake (1991), ÖVD’yi, resmi ödül sistemi ile ödüllendirilmeyen fazladan rol davranışları olarak tanımlamakta ve bu davranışların bireylere, gruplara ve örgüte yönelik davranışlar olduğunu vurgulamaktadır. Ryan (2001) ise, ÖVD'yi, bireyin herhangi bir zorunluluk olmadan, resmi ödül sistemi dışındaki ve örgütün etkili bir şekilde çalışmasına katkı yapan davranışlar olarak tanımlamaktadır.

ÖVD’nin kavramsal yapısını; çalışanların itaat, bağlılık, işbirliği ve katılım olarak adlandırılabilecek birbirine bağlı sorumluluklarını içeren biçimsel rol tanımı dışında kalan davranışları oluşturmaktadır (Acar, 2006). ÖVD'de gönüllülük hususu öne çıkmakla birlikte, acaba her gönüllü davranış ÖVD olarak tanımlanabilir mi sorusu da gündeme gelmektedir. Bu durumda, eğer çalışanın örgüte fayda sağlayan davranışı gönüllü ise; örgüt yöneticileri ve diğer paydaşlar 
açısından olumluluk içeriyorsa ve diğer çalışanlar tarafindan kabul edilebilir nitelikte ise ÖVD olarak tanımlanabileceği söylenebilir (Özdevecioğlu, 2003). ÖVD ile ilgili yapılan tanımlamalar incelendiğinde; çalışanların karşılık beklemeksizin bu davranışları sergilemesi, söz konusu davranışların örgütle ilgili olması, kendiliğindenlik içermesi, isteğe bağlı ve olumlu davranışlar olması öne çıkan özelliklerdir (Karaaslan vd., 2009). ÖVD biçimsel rol tanımları dışında ve örgüte faydalı isteğe bağlı davranışlar olması nedeniyle bu tür davranışların artırılmasında liderin etkisi ve desteğinin özellikle önemli olduğu düşünülmektedir.

\section{Örgütsel Vatandaşlık Davranışının Boyutları}

Smith vd. (1983) tarafindan yapılan araştırmada ÖVD’nin diğerkamlık ve vicdanlılık olmak üzere asgari iki boyutunun olduğu tespit edilmiştir. Organ (1988) ise ÖVD'yi; diğerkâmlık, centilmenlik, nezaket, vicdanlılık ve sivil erdem olarak beş boyutta tanımlamaktadır.

$\mathrm{Bu}$ çalışma kapsamında Organ (1988) tarafından belirlenen diğerkâmlık (özgecilik), centilmenlik (sportmenlik), nezaket, vicdanlılık ve sivil erdem olarak yapılan beş boyutlu sınıflandırma esas alınmıştır. Diğerkâmlık; çalışanların doğrudan ve gönüllü bir şekilde birbirlerine yardım etme davranışları olarak tanımlanmaktadır (Smith vd., 1983). Vicdanlılık; alanyazında ileri görev bilinci olarak da ifade edilmekte olup, örgütün amaçlarına katkı yapmak amacıyla gönüllü olarak, biçimsel rol tanımlarında yer alan sorumluluklardan fazlasının yapılmasını, asgari gerekliliklerin ötesinde sergilenen davranışları içerir (Organ, 1988; George ve Brief, 1992; Bağc1, 2014; Özler, 2015). Nezaket; örgütte bireyin karar ve davranışları konusunda, etkilenebilecek paydaşlarını önceden bilgilendirmesi olarak ifade edilmektedir (Schnake ve Dumler, 2003; Organ, 1988; Sezgin, 2005; Özler, 2015). Centilmenlik; yakınmaktan, küçük şikâyetlerden, gerçek veya sanal pürüzlerden ve küçük olayları büyütmekten kaçınmak olarak tanımlanmaktadır (Organ, 1988). Sivil Erdem; örgütle ilgili konular ve örgütü etkileyen değişimlere ayak uydurmak (Morrison, 1994), örgütün amaçlarını ve çıkarlarını benimsemek, önemsemek, gönüllü olarak örgütle ilgilenme ve örgütle ilgili faaliyetlere katılım olarak tanımlanmaktadır (Sezgin, 2005). 
Liderlik Tarzı ile Örgütsel Vatandaşlık Davranışı İlişkisi:

Bir Özel Eğitim Kurumunda Uygulama

\section{Örgütsel Vatandaşlık Davranışının Öncülleri}

ÖVD ile ilgili çalışmaların büyük çoğunluğunun, bu davranışları oluşturan sebeplerin bilinmek istenmesi nedeniyle, ÖVD'nin öncülleri ile ilgili olduğu görülmektedir (Gürbüz, 2006; Organ ve Ryan, 1995). ÖVD’nin oluşumuna etki eden faktörleri Organ ve Ryan (1995); iş doyumu, dürüstlük, duygusal bağl1lık, devamlılık, lider etkisi, vicdanlılık, uzlaşılabilirlik, pozitif ve negatif duygusallık, iş tecrübesi ve cinsiyet faktörleri olarak, Van Dyne vd. (1994); kişisel (pozitif iş tutumları, alaycılık), algısal (örgütsel değerler, iş özellikleri) ve durumsal (örgütsel mülkiyet, hiyerarşik iş düzeyi) faktörler olarak sınıflandırmaktadır.

Podsakoff vd. (2000) ise ÖVD’yi; bireysel özellikler, örgütsel özellikler, görev özellikleri ve liderlik uygulamaları olmak üzere dört grupta toplamaktadır. Bireysel özellikler; ÖVD'yi belirleyen karakteristikler içinde, çalışanın işle ilgili tutumları ve kişiliği üzerinde araştırmacılar tarafından sıklıkla durulmuş olup, bu kapsamda bireysel özellikler ile ilgili olarak; örgütsel bağl1lık, örgütsel adalet, lider desteği, özsayg1, iş tatmini, bireyin ruhsal durumu (moral), kişilik faktörleri, gereksinimler, güven, tutumlar, rol çatışması/rol belirsizliği, ödüllere kayıtsızlık, yetenek/tecrübe/eğitim/bilgi/bağımsızlık gereksinimi ve demografik değişkenler gibi konulara değinilmiştir (Organ, 1988; Yener ve Akyol, 2009; Özler, 2015). Örgütsel özellikler; Kulaklığlu (2009), örgütsel özellikler kapsamında örgüt kültürünün bireysellik-toplumsallık ve güç mesafesi boyutları açısından ÖVD üzerinde etkili olduğunu ifade etmektedir. Görev özellikleri; işle ilgili geri bildirim, tatmin edici iş ve işin rutinliği başlıkları altında üç kategoride incelenmektedir. İşle ilgili geri bildirim sağlanırsa ve çalışanlar yaptıkları işin tatmin edici olduğunu düşünürse daha fazla ÖVD sergiler. Buna karşın, alışılagelmiş usullerle rutin iş yapanların ise daha az ÖVD sergilediği görülmektedir. ÖVD ile; geri bildirim ve tatmin edici iş pozitif yönlü, iş rutinliği ise negatif yönlü ilişkilidir (Podsakoff vd., 2000; Özler, 2015). Liderlik özellikleri; örgütler için gerekli ve önemli olduğu tespit edildiğinden, ÖVD’nin geliştirilmesi ve özellikle etkili liderlik tarzları ile bu davranışların oluşturulması ve desteklenmesi önerilmektedir. ÖVD'de esas önemli öncül, etkili liderlik tarzının örgütlerde uygulanması olarak ortaya çıkmaktadır (Avc1, 2015). 
Liderlerin davranışları, çalışanların ÖVD göstermeleri ya da göstermemeleri üzerinde son derece önemli olmaktadır. Podsakoff vd. (2000), çalışanların ÖVD sergilemesi ile ilişkisi kapsamında liderlik davranışlarını temelde iki başlık altında toplamakta olup, bunlar; "dönüşümcü lider" davranışları (temel dönüşümcü davranışlar, vizyonu ifade etmek, uygun model olmak, ortak amaçların kabulünü teşvik ve entelektüel uyarım) ve "etkileşimci lider" davranışları (koşullu ödüllendirme ve istisnalarla yönetim) olup, genel olarak dönüşümcü lider davranışlarının ÖVD'nin tüm boyutları ile pozitif ve anlamlı ilişkisi olduğunu, yine etkileşimci liderlik davranışları içinde yer alan koşullu ödüllendirme davranışı ile ÖVD’nin pozitif yönlü anlamlı ilişkisi olduğunu ortaya koymuşlardır.

\section{Örgütsel Vatandaşılk Davranışının Sonuçları}

Özdevecioğlu (2013), ÖVD’nin örgütsel yaşam üzerinde; çalışanların yardımlaşma eğilimini artırmak, sorumluluk duygusunu geliştirmek ve pozitif tutum sergilemeye yardımc1 olmak gibi konularda etkili olduğunu belirtmektedir. Kulaklıŏlu (2009) ÖVD’nin; çalışanların örgütteki kurallara uymasına, bu kuralların benimsenmesine ve yaygınlaştırmaya çalışmada etkili olduğunu, çalışanların örgütsel işleyiş̧e kendi inisiyatifleriyle ve gönüllü olarak yer almasına katkı yaptığını, çalışanların bilgilerini, becerilerini ve yeteneklerini geliştirmeye, artırmaya yönelik faaliyetlerde bulunmasında etkili olduğunu ifade etmektedir. ÖVD'nin sonuçlarını örgütsel performans ve başarı kapsamında değerlendiren (Organ vd., 2006), birlikte çalışan bireylerin ve örgütlerin verimliliğini artırdığını ve kaynakların daha verimli amaçlar için kullanılmasını sağlayarak kıt kaynakları sadece koruyucu bakım işlevlerine tahsis etme gereksinimini azalttığını belirtmektedir. ÖVD çalışanların asli görevlerinden olmayıp, biçimsel rol tanımlarındaki görevlerini desteklemek suretiyle örgütsel ve sosyal çevreyi şekillendirmekte ve örgütsel etkinliğe katkı sağlamakta, bu kapsamda, çalışanlar biçimsel rol tanımlarının ötesinde ve ödül sisteminde yer almayan isteğe bağlı olarak örgüte faydalı davranışlar sergilemektedir (Keleş ve Pelit, 2009).

ÖVD'nin çok fazla araştırılmasının nedenleri; bu davranışlar sonucundaki performans artışının insan kaynakları yönetimi uygulamaları kapsamında terfi ve ücret değerlendirilmelerinde kullanılması, bu davranışların örgütün başarısı ve 
Liderlik Tarzı ile Örgütsel Vatandaşlık Davranışı İlişkisi:

Bir Özel Eğitim Kurumunda Uygulama

etkinliğine olan katkısı ile örgütsel bağlılık, işten ayrılma niyeti, örgütsel adalet ve iş tatmini ile olan ilişkisi olarak ifade edilebilir (Gürbüz, 2006). Araştırmacılar ÖVD ve performans arasında çoğunlukla pozitif yönlü ilişkiler bulmuşlardır. Bireysel düzeyde performans ile ÖVD arasındaki pozitif ilişkinin ÖVD'nin dolaylı olarak performans değerlendirme uygulamaları içinde yer alması, yani ÖVD sergileyen çalışanların sergiledikleri bu davranışların doğrudan görev tanımlarında yer almasa bile yöneticiler tarafindan daha iyi ödüllerle değerlendirilmesi eğiliminde olması ÖVD performans ilişkisine örnek olarak verilebilir (MacKenzie vd., 1991). Podsakoff vd. (2000), ÖVD sonuçlarını; ÖVD'nin performans değerlendirme ve promosyon/ücret artışı gibi konularda kriter olarak kullanılması ile örgütsel performans ve başarıya etkisi boyutlarıyla değerlendirmekte olup, özetle; çalışanların bireysel ve yönetimsel üretkenliğini artırmak, kaynakları özgür bırakmak suretiyle onların daha üretken amaçlar için kullanılması, idame-işletme fonksiyonları için ihtiyaç duyulan kaynağın azaltılması, grup içi ve gruplar arası faaliyetlerin koordinasyonuna yardım etme, örgütün daha iyi çalışanları çekmesi ve elinde tutma gücünün artırılması, örgütsel performansın yükseltilmesi ve örgütün çevresel değişimlere uyum gücünün artırılması olarak sıralamaktadır.

\section{Liderlik}

İnsanoğlu, toplu olarak yaşayan sosyal bir varlık olarak, farklılaşan ihtiyaçlarını karşılamak için gerçekleştirilmesi gereken işleri toplumsal koordinasyon ve yardımlaşma çerçevesinde birlikte yapmak durumundadır. Bu çerçevede liderlik, ortak amaçlara ulaşabilmek için takipçilerin davranışlarını yönlendirme süreci, lider ile takipçiler arasında ortaya çıkan etkileşimden oluşan ilişkiler bütünüdür (Şimşek, 1998).

Liderlik tanımları incelendiğinde genellikle, liderlik sürecinin temelde, bir bireyin diğerlerini etkileyebilmesi ile ilgili olduğu görülmektedir. Bu kapsamda, liderin takipçileri nasıl etkilediği ile bu etkileşim sürecinde hangi faktörlerin rol oynadığı ve bu kapsamda liderin kullandığı güç kaynakları üzerine odaklanıldığı görülmektedir (Demir vd., 2010). Liderlik tarzının şekillenmesinde ve sürecin etkinliğinde gücün kaynakları ve kullanımı özellikle öne çıkmaktadır (Koçel, 2013). Güç, birinin diğerini etkileme potansiyelini içerir ve güç; etkileyeceği hedef 
kitleden, etkinin amacından ve zaman periyodundan ayrı tanımlanamaz (Yukl, 2010). Farklı liderlik tarzlarının takipçiler üzerinde farklı etkiler oluşturması bağlamında ÖVD'nin de liderlik davranışlarından biçimsel rol tanımlarındaki davranışlara göre görece daha fazla etkilenen davranışlar olması nedeniyle uygulanan liderlik tarzı ile ÖVD ilişkisi özellikle öne çıkmaktadır. Liderlikle ilgili yapılan bazı tanımlar Tablo 1'de sunulmuştur.

Tablo 1: Liderlik Tanımları

\begin{tabular}{|l|l|}
\hline Hemphill ve Coons, (1957) & $\begin{array}{l}\text { Ortak amaçları gerçekleştirmek üzere grup aktivitelerini } \\
\text { yönlendirme davranışıdır. }\end{array}$ \\
\hline Katz ve Kahn, (1966) & $\begin{array}{l}\text { Örgütün rutin kuralları ile mekanik uyumu üzerindeki } \\
\text { etkinin artırımıdır. }\end{array}$ \\
\hline Burns, (1978) & $\begin{array}{l}\text { Araçsal, politik, psikososyal ve diğer kaynakların, } \\
\text { takipçilerin güdülerini tatmini için kullanılmasıdır. }\end{array}$ \\
\hline Smircich ve Morgon, (1982) & $\begin{array}{l}\text { Insanların kendileri dişındaki diğer insanların } \\
\text { gerçekliklerini tanımlama ve belirlemede başarının } \\
\text { sağlandığ1 süreçte ortaya çıar. }\end{array}$ \\
\hline Roach ve Behling, (1984) & $\begin{array}{l}\text { Bir amacı gerçekleştirmek için organize olmuş bir grubu } \\
\text { etkileme sürecidir. }\end{array}$ \\
\hline Schein, (1985) & $\begin{array}{l}\text { Kültürün dışında kalarak, daha uyumlu olan değişimi } \\
\text { yaratma yeteneğidir. }\end{array}$ \\
\hline Richards ve Engle, (1986) & $\begin{array}{l}\text { Bir şeylerin başarılması için vizyon yaratma, değer yaratma } \\
\text { ve çevre yaratmayla ilgilidir. }\end{array}$ \\
\hline Jacobs ve Jaques, (1990) & \begin{tabular}{l} 
Ortak eylemler için anlamlı bir amaç ve bu amacı \\
gerçekleştirmek için isteklilik yaratmaktır. \\
\hline Insanların anlayacağı ve bağlanacağ1 birlikte yapmaktan \\
zevk alacağı şeyler yapma sürecidir.
\end{tabular} \\
\hline Drath ve Palus, (1994)
\end{tabular}

Kaynak: Yukl (2010). 
Liderlik Tarzı ile Örgütsel Vatandaşlık Davranışı İlişkisi:

Bir Özel Eğitim Kurumunda Uygulama

Etkili liderliği belirleyen üç ana boyut; liderin özellikleri, takipçinin özellikleri ve durumsal özelliklerdir. Şekil 1'de sunulan ilişkiler ağından hareketle liderlik yaklaşımları ele alınabilir (Yukl, 2010).

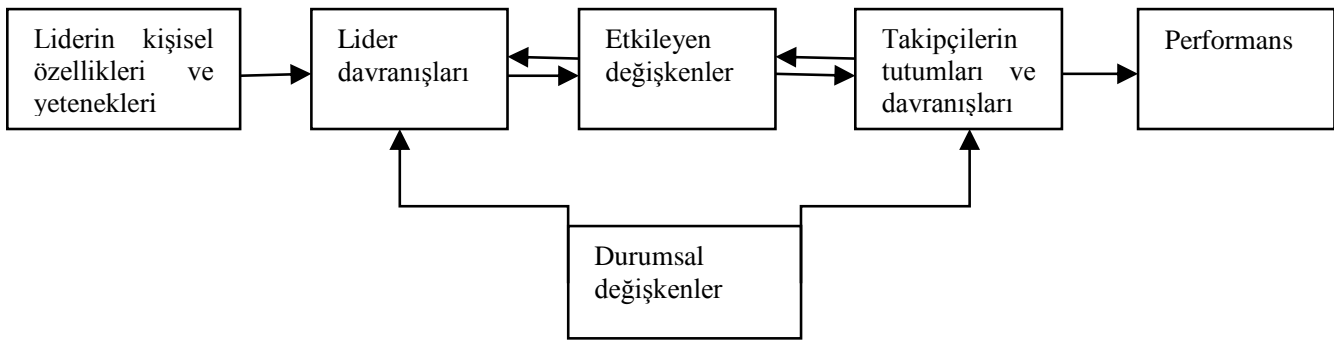

Şekil 1: Liderlik Tarzı Süreçleri Arasındaki İlişki

Kaynak: Yukl (2010)'dan uyarlanmıştır.

Şekil 1'de görüldüğg̈ üzere liderlik tarzı; liderin özellikleri ve yetenekleri, takipçilerin tutum ve davranışları, liderin davranışları ve içinde bulunulan koşullara bağlı olarak ortaya çıkmaktadır. Takip eden bölümde, bu çalışmanın konusu olan dönüşümcü ve etkileşimci liderlik tarzları açıklanmıştır.

\section{Etkileșimci Liderlik Tarzı}

Sabuncuoğlu ve Tüz (2008), 1970'lerde Burns tarafından öne sürülen ve başta Bass gibi diğer araştırmacılar tarafından geliştirilen, işe yönelik olan bu yaklaşımın, bir işi gerçekleştirmek üzere lider ile takipçileri arasındaki işle ilgili karşılıklı ilişkide, liderin davranışları üzerine odaklandığını belirtmektedir.

$\mathrm{Bu}$ yaklaşıma göre, bir amacı gerçekleştirmek üzere lider ve liderlik ettiği grup üyeleri arasındaki ilişki dört farklı türde olabilir: birinci tür davranış; koşullu ödüllendirme olarak da ifade edilebilen ve liderin çalışanların katkıları ve performansı ile bağlantılı olarak onlara kaynak ve destek sağlamasıdır. İkinci ve üçüncü tür davranışlar ise liderin; istisnalarla yönetim olarak da ifade edilebilen ve 
liderin çalışanların işi yaparken onlara karışma ve müdahale etme durumu ile ilgili davranışlardır. Müdahalenin zamanı ve derecesine bağlı olarak aktif veya pasif istisnalarla yönetim davranışları olarak ifade edilebilir. Dördüncü tür davranışta ise; grup üyelerinin işin amaç ve standartlarının belirlenmesinde tamamen serbest bırakılması, işe hiç karışılmaması, bir görüşe göre ise liderlik sorumluluklarının hiçbirinin yerine getirilmemesi olarak ifade edilebilir (Koçel, 2013).

Avolio vd. (1999), etkileşimci liderliğin boyutlarını koşullu ödüllendirme ve istisnalarla yönetim-aktif/pasif olarak tanımlanmaktadır. Koşullu ödüllendirme boyutunda lider, çalışanlardan beklediği performansı açık ve net bir şekilde ortaya koyarak beklenilen performansı gösterenlerin ödüllendirileceğini vaad eder. Başarılı olan çalışanlar vaad edilen ödüller ile ödüllendirilir, yani başarı elde edilmesi koşulunu sağlayan çalışanlar ödüllendirilir (Koçel, 2013). İstisnalarla yönetim boyutu kapsamında; istisnalarla yönetim-aktif boyutunda lider; takipçilerini sürekli izler ve işlerini yaparken belirlenmiş standartların dışına çıkmaları durumunda hemen düzeltici müdahalede bulunur, istisnalarla yönetimpasif boyutunda ise lider; takipçilerinin ciddi problemlere sebep olması, yapılan işlerde standartların karşılanmaması veya hataların ortaya çıkmasından sonra müdahale eder (Demir ve Okan, 2008).

\section{Dönüşümcü Liderlik Tarzı}

Dönüşümcü lider; takipçilerinin ihtiyaçlarını ve değer yargılarını değiştirerek, örgütü değişim ve yenilenmesini sağlayacak performansa ulaştırır (Koçel, 2013). Bu kapsamda dönüşümcü lider, çalışanların örgütsel amaçları benimsemesini ve bu amaçlarla özdeşleşmesini gerçekleştiren bir liderlik tarzıdır (İşcan, 2006). Takipçilerin amaçlara ulaşma konusunda güven duymalarını sağlar, takipçiler için rol model olur, takipçilerin kendilerini adama düzeylerini yükseltir. $\mathrm{Bu}$ yaklaşım kapsamında dört ayrı davranış türü sayılabilir: birinci tür davranış; liderin yüksek moral ve etik standartlar koyarak takipçilerin saygısını ve bağlılıklarını kazanmasıdır. İkinci tür davranış; liderin paylaşılması için çaba sarf ettiği vizyonun takipçilerde yarattığ lidere güven ve izleme arzusu ve lideri ilham kaynağı olarak görmelerine dönük duygusal motivasyon sağlamasıdır. Üçüncü tür davranış; liderin değişim için uygun ortam yaratması, yaratıcı fikirlerle takipçilerin 
Liderlik Tarzı ile Örgütsel Vatandaşlık Davranışı İlişkisi:

Bir Özel Eğitim Kurumunda Uygulama

entellektüel yönlerine hitap etmesi ve onları bu yönde davranmaya yönlendirmesidir. Dördüncü tür davranış ise; takipçilerin katılımını sağladığı, takipçilerine koçluk ve mentorluk yaptığı, gelişmeleri yönünde çaba gösterdiği davranışları ile takipçilerin dönüşmesini sağladığı durum olarak ifade edilebilir (Koçel, 2013).

Avolio vd. (1999) dönüşümcü liderliği; ilham verme, entelektüel uyarım, idealleştirilmiş etki ve bireysel ilgi boyutları ile tanımlanmaktadır. İlham veren motivasyon boyutu; takipçilerinin yaptığ 1 işe ve amaçlarına anlam ve değer katarak rekabetçilik kazandırmak suretiyle, onları, amaçlarını gerçekleştirmek üzere motive edecek şekilde ilham veren liderlik davranışlarıdır (Avolio ve Bass, 2002). Dönüşümcü lider, çalışanları motive ederek kendilerinden beklenenden daha yüksek performans sergilemelerini sağlamak suretiyle onların tutum ve davranışlarında etkin rol oynamaktadır (Avc1, 2015). Entellektüel uyarım boyutunda; dönüşümcü lider, takipçilerinin önyargılarına ve varsayımlara karşı şüphe ile yaklaşmasını, mevcut durumu farklı bakış açılarıyla analiz ederek problemleri yeni çözüm yöntemleri ile ele almasını ve gayretlerinin yenilikçilik ve yaratıcılık odaklı olması yönünde onlara entellektüel uyarım sağlar (Avolio ve Bass, 2002). İdealleştirilmiş etki boyutu; idealleştirilen etki (atfedilen) ve idealleştirilen etki (davranış) şeklinde iki alt boyutu içermektedir. İdealleştirilmiş etki (atfedilen) boyutunda, takipçiler lidere hayranlık duyar ve onu rol model aldıkları için etkilenir, idealleştirilmiş etki (davranış) boyutunda ise liderler, riskleri takipçileri ile paylaşırlar (Yolaç, 2011). Bireye yönelik ilgi boyutunda; dönüşümcü lider, örgütsel amaçlar ve çıkarlarla olduğu kadar takipçilerinin amaç ve çıkarları ile de ilgilenmekte ve önemsemektedir. Takipçilerinin başarısı ve amaçlarını gerçekleştirmesi için onların neye ihtiyaç duyduğunu bireysel düzeyde takip etmekte, ilgilenmekte ve destek sağlamaktadır (Avolio ve Bass, 2002).

\section{Liderlik Tarzı ile Örgütsel Vatandaşlık Davranışı İliş̧kisi}

Yöneticinin bilgi paylaştığı, etkileşime açık, katılımcı ve destekleyici yönetim sergilediği durumlarda çalışanların isteğe bağlı davranışları daha fazla sergiledikleri, bunun yanı sıra bu davranışların yönetici-çalışan ve çalışan-çalışan dayanışmasını ve örgütsel performansı artırdığı tespit edilmiştir (Altuntaş ve 
Baykal, 2010). Morrison (1994) ise, çalışanların ÖVD’yi, ödüllendirilme (etkileşimci liderlik ile ÖVD ilişkisi kapsamında) ile bağlantılı ve işlerinin beklenen bir parçası olarak görme algısında olduklarını ifade etmektedir.

Liderlik, çalışanların duygu ve düşüncelerini etkilemek suretiyle, onların işleri ile ilgili geliştirdikleri tutum ve davranışlarına da şekil vermektedir. ÖVD de liderin etkilediği çalışan tutum ve davranışları olarak karşımıza çıkmaktadır (Özcan vd., 2012). Örgütsel etkinlikte çalışanın amaçları ile örgütsel amaçların birlikte gerçekleştirilmesi önemlidir. Yöneticilerin, çalışanların ÖVD düzeyini belirlemesi ve bu davranışları gösteren çalışanları destekleyip ödüllendirmesiyle çalışanların teşvik edilmesi ve bu sayede örgütsel amaçlara ulaşılması mümkün olabilmektedir (Altuntaş ve Baykal, 2010).

Podsakoff vd. (1996), çeşitli sektörlerden 1539 kişi üzerinde liderlik tarzı ile ÖVD arasındaki ilişkiyi tespit etmek amacıyla yaptıkları çalışmada; bireysel destek ve tatmin edici iş liderlik boyutlarının, çalışanın diğerkâmlık boyutu ile pozitif ilişki içinde olduğunu belirlemişlerdir. Bu sonuçlar, liderini destekleyici gören çalışanların görmeyenlere göre daha yardım sever olduğunu ortaya koymaktadır. Ayrıca, liderin kontrolü dışındaki ödüllere kayıtsızlığın, vicdanlılık boyutu ile negatif yönlü ilişkili olduğu tespit edilmiştir. Ödülleri değerlendiren ve bunların liderin kontrolünde olduğunu düşünen çalışanlar, daha fazla vicdanlılık davranışları sergileyeceklerdir. Vizyon yaratma ve bireysel destek sağlama liderlik boyutlarının, ÖVD'nin centilmenlik boyutu ile pozitif ilişkili olduğu tespit edilmiş olup, bu durum, kendilerine gelecek vizyonu yaratan ve bireysel destek sunan liderlere sahip çalışanların, karşılıklılık normu kapsamında centilmenlik davranışı sergilemelerini sağlayacaktır. Yine aynı çalışmada; üstün performans beklentisi boyutu ile nezaket boyutu ve bireysel ilgi boyutu ile ise sivil erdem boyutları arasında pozitif ilişki olduğu tespit edilmiştir.

Smith vd. (1983), lider desteği ile çalışanın ÖVD ilişkisi üzerine yaptıkları çalışmada, lider desteğinin ÖVD'nin diğerkâmlık boyutu üzerinde iş tatmininin aracılık ettiği dolaylı bir etkisi olduğunu ifade etmektedir. Arslantaş ve Pekdemir, (2007), bir üretim firmasının 233 mavi yakalı çalışanı üzerinde yaptıkları araştırmada; dönüşümcü liderliğin ilham verme ve bireysel düzeyde ilgi boyutları ile çalışanların ÖVD sergilemeleri arasında anlamlı bir ilişki bulmuş; entellektüel uyarım boyutu ile ÖVD arasında ise anlamlı bir ilişki bulamamışlardır. Morçin ve 
Liderlik Tarzı ile Örgütsel Vatandaşlık Davranışı İlişkisi:

Bir Özel Eğitim Kurumunda Uygulama

Morçin (2013) tarafindan, çalışanların ÖVD sergilemeleri için dönüşümcü liderliğin yanı sıra etkileşimci liderlik gibi iş-ödül karşılıklılığına dayanan liderlik tarzının da önemli ve gerekli olduğu belirtilen araştırmada, etkileşimci liderlik ile ÖVD arasında anlamlı bir ilişki olduğu ortaya konulmuştur. Oğuz (2011) tarafindan, 204 ilköğretim öğretmeni üzerinde yapılan araştırmada, yöneticilerin sahip olduğu liderlik tarzlarından dönüşümcü ve etkileşimci liderlik tarzları ile öğretmenlerin ÖVD'si arasında anlamlı bir ilişki olduğu tespit edilmiştir.

Podsakoff vd. (1990), dönüşümcü liderlik ve etkileşimci liderlik tarzlarının boyutlarının ÖVD üzerinde etkili olduğunu ve dönüşümcü liderliğin üç boyutunun (vizyon sağlama, model olma ve grup amaçlarının kabul edilmesine destek) 0.90 gibi yüksek bir korelasyona sahip olduğunu ifade ederek bu üç boyutun temel (core) dönüşümcü liderlik boyutu olarak ele alınabileceğini belirtmektedir. Etkileşimci liderlik (koşullu ödüllendirme boyutu) tarzının ise ÖVD üzerinde doğrudan etkisi olduğunu ortaya koymuşlardır. Bu durum, çalışanların rol içi veya fazladan rol davranışlarının ödüllendirilmesi durumunda, sosyal değişim teorisi kapsamında, ÖVD benzeri olumlu davranışlar göstermeleri yönünde etkileneceği ile açıklanabilir.

\section{Özel Eğitim Kurumunda Çalıșan Öğretmenler Üzerinde Bir Araștırma}

\section{Araştırmanın Amacı ve Önemi}

Liderlik tarzının ÖVD ile teorik olarak beklenilen ilişkiselliği kapsamında, bu çalışmanın temel amacı; yöneticinin liderlik tarzının çalışanların örgütsel vatandaşlık davranışı ile ilişkisinin tespit edilmesidir. Araştırma kapsamında ele alınan ilişkiler; özel eğitim sektöründe çalışan öğretmenler üzerinde incelenmiştir. Yöneticinin liderlik tarzının çalışanın ÖVD'si ile ilişkisinin eğitim sektöründe bir özel eğitim kurumunda test edilmesi ile alanyazına katkı sağlanacağı, uygulamada ise liderlere ne tarz liderlik uygulamalarına ağılık vermeleri konusunda katkı sağlanacağ 1 değerlendirilmektedir. 


\section{Araştırmanın Kapsamı ve Sınırılıkları}

Araştırma, bir özel eğitim kurumunun İstanbul ili Anadolu Yakasında faaliyet gösteren okulları ile sınırlı olarak uygulanmıştır. Yöneticinin dönüşümcü ve etkileşimci liderlik tarzlarının çalışanların sergilediği ÖVD'nin boyutlanı ile ilişkisi araştırılmıştır. Ölçeklerin ölçmeye çalışılan boyutları ölçebilme kapasitesi ölçüm sınırlılığıdır. Bu araştırmanın kapsamını, söz konusu özel eğitim kurumu bünyesinde çalışan öğretmenler oluşturmaktadır. Araştırma yapılan eğitim kurumunda İstanbul ili Anadolu Yakasında 11 okulda toplam 470 öğretmen bulunmaktadır.

\section{Hipotezler ve Araştırma Modeli}

Çalışanların ÖVD gösterme düzeyini etkileyen faktörlerden biri olan liderlik tarzının rolünün netleştirilmesinin, hem uygulamada hem de alanyazına katkı boyutunda faydalı olacağı, bu nedenle söz konusu ilişkinin tespit edilmesinin önemli olduğu değerlendirilmiştir. Araştırmanın temelini oluşturan araştırma problemi bu kapsamda "Çalışanların ÖVD sergilemelerinin, yöneticinin liderlik tarzı ile ilişkisi nedir?” olarak belirlenmiştir. Çalışanların kendilerine yönelik ilgi gösteren, destek davranışları sergileyen, entelektüel uyarım sağlayan, kendilerini ödüllendiren, katılımcı ve kendilerini cesaretlendirme yönünde algıladıkları liderlik davranışlarının, işi için zorunlu olan sorumlulukları yerine getirmenin yanı sıra, örgütün başarısı için gereken ve iş tanımı dışında kalan fazladan çabayı göstermek konusunda da çalışanları motive ettiği daha önce yapılan çalışma sonuçlarında ortaya konulmuştur (Podsakoff vd., 1990; Arslantaş ve Pekdemir, 2007; Morçin ve Morçin, 2013; Oğuz, 2011). Çalışanın ÖVD sergilemesinde; yöneticinin liderlik tarzı önemli bir öncül olarak ortaya çıkmaktadır. Araştırma sorusu bu çerçevede "Eğitim sektöründe çalışan öğretmenlerin ÖVD sergilemeleri ile yöneticinin liderlik tarzı ilişkisi nedir?” olarak belirlenmiştir.

ÖVD öncüllerinden liderlik tarzı ile ÖVD ilişkisi kapsamında hazırlanan ve öğretmenler üzerinde test edilen aşağıda yer alan hipotezlere ilişkin araştırma modeli Şekil 2'de sunulmuştur.

H1: Dönüşümcü liderlik tarzı ile çalışanların örgütsel vatandaşlık davranışı ve boyutları arasında anlamlı ve pozitif ilişki vardır. 
Liderlik Tarzı ile Örgütsel Vatandaşlık Davranışı İlişkisi:

Bir Özel Eğitim Kurumunda Uygulama

H2: Etkileşimci liderlik tarzının koşullu ödüllendirme boyutu ile çalışanların örgütsel vatandaşlık davranışı ve boyutları arasında anlamlı ve pozitif ilişki vardır.



Şekil 2: Araştırma Modeli; Yöneticinin Liderlik Tarzının Çalışanın Örgütsel Vatandaşlık Davranışları ile İlişkisi

Şekil 2'de, yöneticinin liderlik tarzı kapsamında hem dönüşümcü liderliğin hem de etkileşimci liderliğin koşullu ödüllendirme davranışının çalışanların ÖVD sergilemeleri ile doğrudan ilişkili olduğu bir model ile ifade edilmiştir.

\section{Araştırmanın Yöntemi, Evren ve Örneklem}

Araştırmada kullanılan yöntem; amaç bakımından uygulamalı, yürütüldüğü ortam bakımından alan araştırması, içerik bakımından niceldir. Alan araştırmasında veriler anket yöntemi ile toplanmıştır. Araştırmanın evreni bir özel eğitim kurumunun İstanbul ili Anadolu Yakası Bölgesinde 11 okulda çalışan 470 öğretmen olarak belirlenmiştir. Dağıtılan 370 anketin 295 adedi denekler tarafından doldurulmuştur. 


\section{Veri Toplama Araçları ve Veri Değerlendirme Tekniği}

ÖVD ölçeği olarak; Vey ve Campbell (2004) ile Williams ve Shiaw (1999)'a ait iki ayrı çalışmadan yararlanılarak Basım ve Şeşen (2006) tarafından Türkçe'ye çevrilen ve geçerliliği ve güvenilirliği test edilmiş, araştırmacılar tarafından kullanılmış, 19 maddeden oluşan ÖVD ölçeği pilot uygulama sonrasında 18 madde olarak kullanılmıştır.

Liderlik tarzı ölçeği olarak; Yurtkoru (2001) tarafından Türkçe'ye çevrilen ve geçerliliği ve güvenilirliği test edilmiş, araştırmacılar tarafindan kullanılmış, Bass ve Avolio (2000)'nun Çoklufaktör Liderlik Anketi (Multifactor Leadership Questionnare)'den uyarlanmış 36 maddeli liderlik tarzı ölçeği pilot uygulama sonrasında 20 madde olarak kullanılmıştır.

Toplanan verilerin analizi SPSS ve Amos programları ile yapılmıştır. Güvenilirlik analizleri Cronbach Alpha güvenirlik katsayısı kullanılarak yapılmış olup, geçerlilik için ise açıklayıcı ve doğrulayıcı faktör analizleri yapılmıştır. Ankette yer alan önermelerin değerlendirilmesi, 5'li Likert ölçeğinde yapılmıştır. Likert Ölçeğinde "1: Kesinlikle Katılmıyorum", “2: Katılmıyorum”, “3: Kararsızım", "4: Katılıyorum” ve "5: Kesinlikle Katılıyorum” olarak kullanılmıştır. Hipotez testleri ile birlikte betimleyici istatistikler (ortalama, standart sapma vb.) kullanılarak değişkenler tanımlanmıştır.

Ölçümün geçerliliği için gerekli ilk kriter güvenilirliktir. Güvenilirlik ölçümünde Cronbach Alpha'nın ,60 ve üzerinde olması gerekir (Karasar, 2005). Özdamar (2002) tarafından, güvenirlik katsayısına ilişkin Cronbach Alpha ölçüt değerleri; “, $00<\alpha<, 40 ”$ güvenilir değil, “, $41<\alpha<, 60 ”$ düşük güvenilirlik, “, $61<\alpha<, 80$ ” orta düzeyde güvenilir ve ", $81<\alpha<1,00$ ” yüksek düzeyde güvenilir olarak belirtilmektedir. Örneklem büyüklügünün belirlenmesi kapsamında, temel bileşenler faktör analizinde her bir değişkene karşıllk 5-10 deneğin, doğrulayıcı faktör analizinde (DFA) 20 kat ve daha fazla deneğin olması beklenmektedir (Coşkun vd., 2015). Faktör analizi ölçeğin yapı geçerliliğinin ortaya konulmasını sağlayan analiz yöntemidir. Örneklem yeterliliği, anlamlılık vb. bazı istatistik değerlerin veri setinin faktör analizine uygunluğunu ortaya koyması ve aynı faktörü ölçen maddelerin birbiriyle ilişkili olacak şekilde gruplaşması gerekmektedir (Büyüköztürk, 2016). DFA, ölçülen değişkenlerin temsil ettiği örtük değişkenlerin 
Liderlik Tarzı ile Örgütsel Vatandaşlık Davranışı İlişkisi:

Bir Özel Eğitim Kurumunda Uygulama

tanımlanması, ölçek geliştirme ve belirlenmiş faktör yapısı kapsamında geçerlilik analizi veya tespit edilmiş yapının doğrulanması için kullanılmaktadır (Bayram, 2010). Açıklayıcı faktör analizinde (AFA) güvenilirlik, anlamlılık ve örneklem yeterliliğinin tespit edilmesi için, Barlett's küresellik testi; korelasyon matrisindeki tüm değişkenlerle ilgili korelasyonların genel anlamlılıklarını gösterir, KaiserMeyer-Olkin (KMO) testi; faktör analizinin uygunluğunu gösteren bir değerdir. KMO değeri “,5-1,0” arası kabul edilebilir değerler; ,5'in altındaki değerler ise kabul edilemez olduğunun göstergesidir. Genel olarak ise KMO değerinin asgari ,70 olması istenir. Örneklem yeterlik değeri (Measures of Samplin AdequacyMSA); MSA değerinin yorumlanmasında şunlar dikkate alınmalıdır; ",8 ve üzeri” değerler yüksek, “,7-,8 arası” değerler orta; “,6-,7 arası” değerler vasat; “,5-,6 arası” değerler zayıf; ",5'in altı” değerler güvenilmez (Coşkun vd., 2015). DFA uyum iyiliğinin belirlenmesi kapsamında en fazla kullanılan veriler; $\chi 2$, GFI, AGFI, RMR ve RMSEA olarak sayllabilir. Ki-kare istatistiği; " $\chi 2 / \mathrm{df}<2$ " ise mükemmel uyumu ve " $\chi 2 / \mathrm{df}<3$ " ise iyi uyumu ve " $\chi 2 / \mathrm{df}<5$ " kabul edilebilir bir uyumu, uyum iyiliği indeksi (GFI) ve AGFI; ,85 veya üstü kabul edilir uyumu, RMR değeri ,05 ve daha düşük kabul edilebilir uyumu, yaklaşık hataların ortalama kare kökünün (RMSEA) ,08'den küçük olması kabul edilebilir uyumu gösterir (Bryne, 2001; Meydan ve Şeşen, 2015).

Araştırmada bağımlı ve bağımsız değişkenler arasında negatif veya pozitif ilişkiyi belirlemek üzere korelasyon analizi uygulanmıştır. Korelasyon analizi sonuçları elde edilen katsayı kesim noktalarına göre yorumlanmaktadır (Kalaycı, 2006); " $r=, 00-, 25$ ” çok zayıf, "r=,26-,49” zayıf, " $r=, 50-, 69$ ” orta, " $r=, 70-, 89$ ” yüksek ve "r=,90-1,00" çok yüksek.

\section{Pilot Uygulama ve Elde Edilen Sonuçlar}

Araştırmanın uygulama aşamasında, örneklem olarak seçilen kümenin az sayıdaki birimi üzerinde ön uygulama yapılması faydalıdır. Pilot uygulamanın amac1, anket formundaki hataların belirlenerek bu hataların düzeltilmesi ve anket formunun kullanım amaçlarına uygunluğunun denetlenmesidir (Özdamar, 2002). Hazırlanan anket formu ile araştırma kapsamında yer alan iki okulda çalışan 100 öğretmenden anketi dolduran 66 öğretmen üzerinde pilot uygulama yapılmıştır. 
Pilot uygulama sonucunda; yapılan istatistiksel analizler doğrultusunda ÖVD'ye ilişkin bir madde MSA değeri 0,50'nin altında olması nedeniyle ve liderlik tarzına ilişkin 16 madde MSA değeri 0,50'nin altında olması, tek başına bir faktör olarak çıkması, en yüksek değer aldığı iki faktörün faktör yükleri arasında 0,10 'dan daha fazla fark olmaması vb. nedenlerle anket formundan çıkarılmış ve ana uygulamada ÖVD ölçeği 18 madde ve liderlik tarzı ölçeği 20 madde olarak uygulanmıştır.

\section{Ana Uygulamada Örgütsel Vatandaşlık Davranışı ve Liderlik Tarzı Ölçeklerinin Geçerlik ve Güvenilirlik Analizlerine İlişsin Bulgular}

Örgütsel Vatandaşlık Davranışı Ölçeği Güvenilirlik ve Faktör Analizi; açıklayıcı faktör analizinde, KMO ve Barlett's testinde (KMO değeri ,779 ve Barlett's değeri 2674,882) p(sign.)=,000<,05 olduğundan KMO ve Bartlett's testi anlamlıdır. Örneklem büyüklüğü yeterlidir. Açıklanan kümülatif varyans miktarı, toplam varyansın \%76,2'sidir. Güvenilirlik kapsamında Cronbach Alfa değerleri; ÖVD için ,855, ÖVDD için ,681, ÖVDV için ,827, ÖVDN için ,784, ÖVDC için ,757 ve ÖVDSE için ,757 olarak bulunmuş olup güvenilirlik sağlanmaktadır. Ayrıca, ÖVD ölçeğinin yapı geçerliliğinin doğruluğu ve uyumu birinci düzey doğrulayıcı faktör analizi ile test edilmiştir. Uyum iyiliği kriterleri incelendiğinde $\mathrm{X}^{2} / \mathrm{Sd}=2,567$ bulunmuştur ve $\mathrm{X}^{2} / \mathrm{Sd}$ değeri 3 ve daha düşük olduğunda model uyumunun iyi olduğu kabul edilmektedir. GFI $=, 895$, AGFI $=, 856, \mathrm{RMR}=, 038$, RMSEA $=, 073$ bulunmuş ve bu değerler kabul edilebilir uyumu göstermektedir.

Liderlik Tarzı Ölçeği Güvenilirlik ve Faktör Analizi; açıklayıcı faktör analizinde, KMO ve Barlett's testinde (KMO değeri ,834 ve Barlett's değeri 2006,674) p(sign.) $=, 000<, 05$ olduğundan KMO ve Bartlett's testi anlamlıdır. Örneklem büyüklüğü yeterlidir. Açıklanan kümülatif varyans miktarı, toplam varyansın \%70,2'sidir. Güvenilirlik kapsamında Cronbach Alfa değerleri; liderlik tarzı için ,673; DL için ,846 ve ELKÖ için ,699 olarak bulunmuş olup güvenilirlik sağlanmaktadır. Ayrıca, LT ölçeğinin yapı geçerliliğinin doğruluğu ve uyumu birinci düzey doğrulayıcı faktör analizi ile test edilmiştir. Analizde bir modifikasyon uygulanmış olup uyum iyiliği kriterleri incelendiğinde $\mathrm{X}^{2} / \mathrm{Sd}=2,44$ bulunmuştur ve $\mathrm{X}^{2} / \mathrm{Sd}$ değeri 3 ve daha düşük olduğunda model uyumunun iyi 
Liderlik Tarzı ile Örgütsel Vatandaşlık Davranışı İlişkisi:

Bir Özel Eğitim Kurumunda Uygulama

olduğu kabul edilmektedir. GFI $=, 894, \mathrm{AGFI}=, 861, \mathrm{RMR}=, 049$ ve RMSEA $=$ ,070 bulunmuş olup, bu değerler kabul edilebilir uyumu göstermektedir.

\section{Betimsel Analiz Bulguları}

Araştırmaya katılan öğretmenlerin "ÖVDD” düzeyi çok yüksek $(4,484 \pm, 433)$; “ÖVDV” düzeyi çok yüksek $(4,357 \pm, 592)$; “ÖVDN” düzeyi çok yüksek $(4,611 \pm, 505)$; “ÖVDC” düzeyi çok yüksek $(4,253 \pm, 554)$; “ÖVDSE” düzeyi çok yüksek $(4,204 \pm, 612)$ ve "ÖVD (genel)" düzeyi çok yüksek $(4,371 \pm, 374)$ olarak tespit edilmiştir. Araştırmaya katılan öğretmenlerin algıladığı, yöneticinin "DL" düzeyi yüksek $(4,033 \pm, 488)$ ve "ELKÖ” düzeyi çok yüksek $(4,226 \pm, 604)$ olarak tespit edilmiştir.

\section{Değiş̧kenler Arasındaki İlişkilerin İncelenmesi ve Hipotezlerin Test Edilmesine İlișkin Bulgular}

Araştırma bulguları \%95 güven aralığı \%5 anlamlılık düzeyinde değerlendirilmiştir. Değişkenler arasındaki ilişkileri ortaya koymak amacıyla hazırlanan korelasyon değerlerine Tablo 2'de yer verilmiş olup, takiben hipotezlere ilişkin değerlendirmeler sunulmuştur. 
Tablo 2: ÖVD ve Liderlik Tarzı Korelasyon Tablosu

\begin{tabular}{|l|l|c|c|c|c|c|c|c|c|}
\hline & & $\mathbf{1}$ & $\mathbf{2}$ & $\mathbf{3}$ & $\mathbf{4}$ & $\mathbf{5}$ & $\mathbf{6}$ & $\mathbf{7}$ & $\mathbf{8}$ \\
\hline \multirow{2}{*}{ 1. ÖVDD } & $\mathrm{r}$ & 1,000 & & & & & & & \\
\hline & $\mathrm{p}$ & 0,000 & & & & & & & \\
\hline \multirow{2}{*}{ 2. ÖVDV } & $\mathrm{r}$ &, $258^{* *}$ & 1,000 & & & & & & \\
\hline & $\mathrm{p}$ &, 000 &, 000 & & & & & & \\
\hline \multirow{2}{*}{ 3. ÖVDN } & $\mathrm{r}$ &, $347^{* *}$ &, $288^{* *}$ & 1,000 & & & & & \\
\hline & $\mathrm{p}$ &, 000 &, 000 &, 000 & & & & & \\
\hline \multirow{2}{*}{ 4. ÖVDC } & $\mathrm{r}$ &, $401^{* *}$ &, $427^{* *}$ &, $386^{* *}$ & 1,000 & & & & \\
\hline & $\mathrm{p}$ &, 000 &, 000 &, 000 &, 000 & & & & \\
\hline \multirow{2}{*}{ 5. ÖVDSE } & $\mathrm{r}$ &, $291^{* *}$ &, $410^{* *}$ &, $236^{* *}$ &, $374^{* *}$ & 1,000 & & & \\
\hline & $\mathrm{p}$ &, 000 &, 000 &, 000 &, 000 &, 000 & & & \\
\hline \multirow{2}{*}{$\begin{array}{c}\text { 6. ÖVD } \\
\text { (Genel) }\end{array}$} & $\mathrm{r}$ &, $642^{* *}$ &, $686^{* *}$ &, $604^{* *}$ &, $769^{* *}$ &, $724^{* *}$ & 1,000 & & \\
\hline & $\mathrm{p}$ &, 000 &, 000 &, 000 &, 000 &, 000 &, 000 & & \\
\hline \multirow{2}{*}{ 7. DL } & $\mathrm{r}$ &, $197^{* *}$ &, $229^{* *}$ &, $231^{* *}$ &, $390^{* *}$ &, $250^{* *}$ &, $383^{* *}$ & 1,000 & \\
\hline & $\mathrm{p}$ &, 001 &, 000 &, 000 &, 000 &, 000 &, 000 &, 000 & \\
\hline \multirow{2}{*}{ 8. ELKÖ } & $\mathrm{r}$ &, $450^{* *}$ &, $152^{* *}$ &, $182^{* *}$ &, $175^{* *}$ &, 079 &, $283^{* *}$ &, $154^{* *}$ & 1,000 \\
\hline & $\mathrm{p}$ &, 000 &, 009 &, 002 &, 003 &, 178 &, 000 &, 008 &, 000 \\
\hline
\end{tabular}

H1: Dönüşümcü liderlik tarzı ile çalışanların örgütsel vatandaşlık davranışı arasında anlamlı ve pozitif ilişki vardır.

Hla: Dönüşümcü liderlik tarzı ile çalışanların örgütsel vatandaşlık davranışının diğerkâmlık boyutu arasında anlamlı ve pozitif ilişki vardır.

HIb: Dönüşümcü liderlik tarzı ile çalışanların örgütsel vatandaşlık davranışının vicdanlılık boyutu arasında anlamlı ve pozitif ilişki vardır.

H1c: Dönüşümcü liderlik tarzl ile çalışanların örgütsel vatandaşlık davranışının nezaket boyutu arasında anlamlı ve pozitif ilişki vardır.

H1d: Dönüşümcü liderlik tarzı ile çalışanların örgütsel vatandaşlık davranışının centilmenlik boyutu arasında anlamlı ve pozitif ilişki vardır. 
Liderlik Tarzı ile Örgütsel Vatandaşlık Davranışı İlişkisi:

Bir Özel Eğitim Kurumunda Uygulama

Hle: Dönüşümcü liderlik tarzı ile çalışanların örgütsel vatandaşlık davranışının sivil erdem boyutu arasında anlamlı ve pozitif ilişki vardır.

DL ve ÖVDD arasında çok zayıf, pozitif yönlü anlamlı ilişki bulunmuştur (r=,197; $\mathrm{p}=, 001<, 05)$. DL ve ÖVDV arasında çok zayıf, pozitif yönlü anlamlı ilişki bulunmuştur ( $r=229 ; \mathrm{p}=, 000<, 05)$. DL ve ÖVDN arasında çok zayıf, pozitif yönlü anlamlı ilişki bulunmuştur $(\mathrm{r}=, 231 ; \mathrm{p}=, 000<, 05)$. DL ve ÖVDC arasında zayıf, pozitif yönlü anlamlı ilişki bulunmuştur $(\mathrm{r}=, 390 ; \mathrm{p}=, 000<, 05)$. DL ve ÖVDSE arasında çok zayıf, pozitif yönlü anlamlı ilişki bulunmuştur $(r=, 250 ; p=, 000<, 05)$. DL ve ÖVD (Genel) arasında zayıf, pozitif yönlü anlamlı ilişki bulunmuştur $(\mathrm{r}=, 383 ; \mathrm{p}=, 000<, 05)$. H1 hipotezine ilişkin korelasyon değerleri Tablo 3'te sunulmuştur.

Tablo 3: H1 Hipotezi Test Sonuçları

\begin{tabular}{|c|c|c|c|c|}
\hline No & Hipotez & $\mathbf{p}$ & $\mathbf{r}$ & Durum \\
\hline H1 & $\begin{array}{l}\text { Dönüşümcü liderlik tarzı ile çalışanların } \\
\text { örgütsel vatandaşlık davranışı arasında anlamlı } \\
\text { ve pozitif ilişki vardır. }\end{array}$ &, $000<, 05$ & ,383 & KABUL \\
\hline H1a & $\begin{array}{l}\text { Dönüşümcü liderlik tarzı ile çalışanların örgütsel } \\
\text { vatandaşlık davranışının diğerkâmlık boyutu } \\
\text { arasında anlamlı ve pozitif ilişki vardır. }\end{array}$ &, $001<, 05$ & ,197 & KABUL \\
\hline H1b & $\begin{array}{l}\text { Dönüşümcü liderlik tarzı ile çalışanların örgütsel } \\
\text { vatandaşlık davranışının vicdanlılık boyutu } \\
\text { arasında anlamlı ve pozitif ilişki vardır. }\end{array}$ &, $000<, 05$ & ,229 & KABUL \\
\hline H1c & $\begin{array}{l}\text { Dönüşümcü liderlik tarzı ile çalışanların örgütsel } \\
\text { vatandaşlık davranışının nezaket boyutu arasında } \\
\text { anlamlı ve pozitif ilişki vardır. }\end{array}$ &, $000<, 05$ & ,231 & KABUL \\
\hline H1d & $\begin{array}{l}\text { Dönüşümcü liderlik tarzı ile çalışanların örgütsel } \\
\text { vatandaşlık davranışının centilmenlik boyutu } \\
\text { arasında anlamlı ve pozitif ilişki vardır. }\end{array}$ &, $000<, 05$ & ,390 & KABUL \\
\hline H1e & $\begin{array}{l}\text { Dönüşümcü liderlik tarzı ile çalışanların örgütsel } \\
\text { vatandaşlık davranışının sivil erdem boyutu } \\
\text { arasında anlamlı ve pozitif ilişki vardır. }\end{array}$ &, $000<, 05$ & 250 & KABUL \\
\hline
\end{tabular}


H1, H1a, H1b, H1c, H1d ve H1e hipotezlerinin test edilmesi kapsaminda korelasyon tablosundaki değerler incelendiğinde DL ve ÖVD (Genel) ile ÖVD'nin tüm boyutları arasında ,197 ile ,383 arasında değişen çok zayıf ve zayıf pozitif yönlü anlamlı ilişkiler olduğu tespit edilmiş olup H1, H1a, H1b, H1c, H1d ve H1e hipotezleri kabul edilmiştir.

H2: Etkileşimci liderlik tarzının koşullu ödüllendirme boyutu ile çalışanların örgütsel vatandaşlık davranışı arasında anlamlı ve pozitif ilişki vardır.

H2a: Etkileşimci liderlik tarzının koşullu ödüllendirme boyutu ile çalışanların örgütsel vatandaşlık davranışının diğerkâmlık boyutu arasında anlamlı ve pozitif ilişki vardır.

H2b: Etkileşimci liderlik tarzının koşullu ödüllendirme boyutu ile çalışanların örgütsel vatandaşlık davranışının vicdanlılık boyutu arasında anlamlı ve pozitif ilişki vardır.

H2c: Etkileşimci liderlik tarzının koşullu ödüllendirme boyutu ile çalışanların örgütsel vatandaşlık davranışının nezaket boyutu arasında anlamlı ve pozitif ilişki vardır.

H2d: Etkileşimci liderlik tarzının koşullu ödüllendirme boyutu ile çalışanların örgütsel vatandaşlık davranışının centilmenlik boyutu arasında anlamlı ve pozitif ilişki vardır.

H2e: Etkileşimci liderlik tarzının koşullu ödüllendirme boyutu ile çalışanların örgütsel vatandaşlık davranışının sivil erdem boyutu arasında anlamlı ve pozitif ilişki vardır.

ELKÖ ve ÖVDD arasında zayıf, pozitif yönlü anlamlı ilişki bulunmuştur $(\mathrm{r}=, 450 ; \mathrm{p}=, 000<, 05)$. ELKÖ ve ÖVDV arasında çok zayıf, pozitif yönlü anlamlı ilişki bulunmuştur $(r=, 152 ; p=, 009<, 05)$. ELKÖ ve ÖVDN arasında çok zayıf, pozitif yönlü anlamlı ilişki bulunmuştur $(\mathrm{r}=, 182 ; \mathrm{p}=, 002<, 05)$. ELKÖ ve ÖVDC arasında çok zayıf, pozitif yönlü anlamlı ilişki bulunmuştur $(r=, 175 ; p=, 003<, 05)$. ELKÖ ve ÖVD (Genel) arasında zayıf, pozitif yönlü anlamlı ilişki bulunmuştur $(\mathrm{r}=, 283 ; \mathrm{p}=, 000<, 05)$. ELKÖ ile ÖVDSE $(\mathrm{p}=, 178>, 05)$ arasında ise anlamlı bir ilişki bulunmadığ 1 tespit edilmiştir. H2 hipotezine ilişkin korelasyon değerleri Tablo 4'te sunulmuştur. 
Liderlik Tarzı ile Örgütsel Vatandaşlık Davranışı İlişkisi:

Bir Özel Eğitim Kurumunda Uygulama

Tablo 4: H2 Hipotezi Test Sonuçları

\begin{tabular}{|c|c|c|c|c|}
\hline No & Hipotez & $\mathbf{p}$ & $\mathbf{r}$ & Durum \\
\hline H2 & $\begin{array}{l}\text { Etkileşimci liderlik } \text { tarzının }^{2} \text { koşullu } \\
\text { ödüllendirme boyutu ile çalışanların örgütsel } \\
\text { vatandaşlık davranışı arasında anlamlı ve } \\
\text { pozitif ilişki vardır. }\end{array}$ &, $000<, 05$ & ,283 & KABUL \\
\hline H2a & $\begin{array}{l}\text { Etkileşimci liderlik tarzının koşullu ödüllendirme } \\
\text { boyutu ile çalışanların örgütsel vatandaşlık } \\
\text { davranışının diğerkâmlık boyutu arasında anlamlı } \\
\text { ve pozitif ilişki vardır. }\end{array}$ &, $000<, 05$ & ,450 & KABUL \\
\hline H2b & $\begin{array}{l}\text { Etkileşimci liderlik tarzının koşullu ödüllendirme } \\
\text { boyutu ile çalışanların örgütsel vatandaşlık } \\
\text { davranışının vicdanlılık boyutu arasında anlamlı ve } \\
\text { pozitif ilişki vardır. }\end{array}$ &, $009<, 05$ & ,152 & KABUL \\
\hline H2c & $\begin{array}{l}\text { Etkileşimci liderlik tarzının koşullu ödüllendirme } \\
\text { boyutu ile çalışanların örgütsel vatandaşlık } \\
\text { davranışının nezaket boyutu arasında anlamlı ve } \\
\text { pozitif ilişki vardır. }\end{array}$ &, $002<, 05$ & ,182 & KABUL \\
\hline H2d & $\begin{array}{l}\text { Etkileşimci liderlik tarzının koşullu ödüllendirme } \\
\text { boyutu ile çalışanların örgütsel vatandaşlık } \\
\text { davranışının centilmenlik boyutu arasında pozitif } \\
\text { yönlü anlamlı bir ilişki vardır. }\end{array}$ &, $003<, 05$ & , 175 & KABUL \\
\hline H2e & $\begin{array}{l}\text { Etkileşimci liderlik tarzının koşullu ödüllendirme } \\
\text { boyutu ile çalışanların örgütsel vatandaşlık } \\
\text { davranışının sivil erdem boyutu arasında anlamlı } \\
\text { ve pozitif ilişki vardır. }\end{array}$ &, $178>, 05$ & - & RED \\
\hline
\end{tabular}

$\mathrm{H} 2, \mathrm{H} 2 \mathrm{a}, \mathrm{H} 2 \mathrm{~b}, \mathrm{H} 2 \mathrm{c}, \mathrm{H} 2 \mathrm{~d}$ ve H2e hipotezlerinin test edilmesi kapsaminda korelasyon tablosundaki değerler incelendiğinde ELKÖ ve ÖVD (Genel) ile ÖVD'nin boyutlarından ÖVDSE hariç tamamı arasında ,152 ile ,450 arasında değişen çok zayıf ve zayıf pozitif yönlü anlamlı ilişkiler olduğu tespit edilmiş olup $\mathrm{H} 3, \mathrm{H} 3 \mathrm{a}, \mathrm{H} 3 \mathrm{~b}, \mathrm{H} 3 \mathrm{c}$ ve $\mathrm{H} 3 \mathrm{~d}$ hipotezleri kabul edilmiş ve $\mathrm{H} 3 \mathrm{e}$ hipotezi reddedilmiştir. 


\section{Tartışma ve Sonuç}

Çalışanların birbiri ile ve liderleri ile olan ilişkileri sosyal alışveriş kuramı ve karşılıklılık normu çerçevesinde ele alındığında, biçimsel rol davranışlarının dışındaki davranışların da karşılıklılık ilkesi kapsamında ödül ve maliyetler açısından açıklanabileceği değerlendirilmektedir (Ritzer, 1996). Liderlik davranışları açısından, dönüşümcü ve etkileşimci liderliğin koşullu ödüllendirme davranışlarının ÖVD'nin açıklanmasında önemli rol oynadığı (Podsakoff vd., 1990; Arslantaş ve Pekdemir, 2007; Morçin ve Morçin, 2013; Oğuz, 2011) düşünülmekte olup, çalışanların algıladığı dönüşümcü liderlik ve etkileşimci liderliğin koşullu ödüllendirme davranışlarının, işi için zorunlu olan sorumlulukları yerine getirmenin yanı sıra, örgütün başarısı için gereken ve iş tanımı dışında kalan fazladan çabayı göstermek konusunda çalışanları motive etmesi beklenmektedir.

$\mathrm{Bu}$ çalışmada elde edilen bulgular kapsamında; çalışanların yöneticinin uyguladığı liderlik tarzlarından etkileşimci liderlik tarzının koşullu ödüllendirme boyutuna ilişkin algılarının ortalamasının 4,226 puan ile çok yüksek ve dönüşümcü liderlik tarzı ortalamasının 4,033 puan ile yüksek olduğu tespit edilmiştir. $\mathrm{Bu}$ bulgular çerçevesinde çalışanların yöneticinin etkileşimci liderliğin koşullu ödüllendirme davranışına ilişkin algısının dönüşümcü liderlik davranışlarına ilişkin algısına göre daha yüksek olduğu görülmektedir.

Çalışanların sergiledikleri ÖVD ile ilgili bulgular incelendiğinde ÖVD (Genel) düzeyinin 4,374 puan ile çok yüksek olduğu tespit edilmiştir. Nezaket boyutunun diğer ÖVD boyutlarına nazaran daha yüksek (ortalama puan 4,484) olduğu görülmektedir. Dolayısıyla, çalışanların yapacağı işlem veya aldığı kararlardan etkilenecek olan paydaşlarını bilgilendirme davranışlarını sergileme konusunda daha yüksek bir eğilimi olduğu ifade edilebilir. Bununla birlikte, çalışanların örgütü etkileyen olaylarla ilgili sorumluluk hissetmeleri, alınan kararlara ve toplantılara sorumluluk duygusu içinde gönüllü bir şekilde katılmaları ile ilgili sivil erdem boyutu kapsamındaki davranışların diğer boyutlara nazaran daha düşük (ortalama puan 4,204) olduğu tespit edilmiştir. Sivil erdem boyutundaki ÖVD sergileme eğiliminin diğer boyutlarla kıyaslandığında düşük olması, çalışanların kurumsal kararlara katılımı ve benimsemesi konusunda diğer boyutlardaki davranışlara göre daha zayıf olduğunu göstermekte olup, bu durum 
Liderlik Tarzı ile Örgütsel Vatandaşlık Davranışı İlişkisi:

Bir Özel Eğitim Kurumunda Uygulama

çalışanların örgütün amaçlarını ve çıkarlarını benimsemesi, önemsemesi, örgütü etkileyen değişimlere ayak uydurması vb. kritik konularda zafiyete sebep olabileceği şeklinde yorumlanabilir.

Araştırmada değişkenler arası ilişkilerin incelenmesi kapsamında ÖVD bağımlı değişken olarak ele alınmış olup, temel amaç; ÖVD'nin öncülleri arasında bulunan dönüşümcü liderlik ve etkileşimci liderlik tarzının koşullu ödüllendirme boyutu ile ilişkisinin belirlenmesidir.

Dönüşümcü liderlik ile çalışanların ÖVD sergilemeleri arasındaki ilişki incelendiğinde; dönüşümcü liderlik ile çalışanların ÖVD'si arasında bütünsel olarak anlamlı ve pozitif (zayıf düzeyde ilişki, r=,383) bir ilişki olduğu, ÖVD’nin boyutları ile ilişkisine ayrı ayrı bakıldığında ise, olumsuz durumlarda şikayet etmeme ve örgütün çıkarları için kendi çıkarlarından vazgeçme davranışlarını içeren centilmenlik boyutu (zayıf düzeyde ilişki, $r=, 390$ ) ile en yüksek olmak üzere tüm boyutları ile anlamlı ve pozitif bir ilişki olduğu bulunmuştur. Çalışanların ÖVD sergilemeleri ile bağımsız değişkenlerden dönüşümcü liderliğin; Özcan vd. (2012), Podsakoff vd. (1990) ve Oğuz (2011)'un bulgularına benzer şekilde anlamlı ve pozitif (zayıf düzeyde ilişki, r=,383) ilişkili olduğu tespit edilmiştir.

Etkileşimci liderliğin koşullu ödüllendirme davranışı ile çalışanların ÖVD sergilemeleri arasındaki ilişki incelendiğinde; etkileşimci liderliğin koşullu ödüllendirme davranışı ile çalışanların ÖVD'si arasında bütünsel olarak anlamlı ve pozitif (zayıf düzeyde ilişki, r=,283) bir ilişki olduğu, gönüllü olarak örgütle ilgilenme ve örgütle ilgili faaliyetlere katılım sağlama davranışlarını içeren sivil erdem boyutu ile arasında anlamlı bir ilişki bulunmadığı ve çalışanların doğrudan ve gönüllü bir şekilde birbirine yardım etme davranışlarını içeren diğerkâmlık boyutu (zayıf düzeyde ilişki, $r=450$ ) ile en yüksek olmak üzere diğer boyutlarının tümüyle anlamlı ve pozitif bir ilişki olduğu bulunmuştur. Çalışanların ÖVD sergilemeleri ile bağımsız değişkenlerden etkileşimci liderliğin koşullu ödüllendirme davranışının; Morçin ve Morçin (2013), Podsakoff vd. (1990) ve Oğuz (2011)'un bulgularına benzer şekilde anlamlı ve pozitif (zayıf düzeyde ilişki, $\mathrm{r}=$,283) ilişkili olduğu tespit edilmiştir.

Podsakoff vd. (1990) tarafindan yapılan araştırmada dönüşümcü ve etkileşimci liderlik tarzları ile ÖVD arasında anlamalı ve pozitif güçlü bir ilişki 
olduğu bulunmuş, bu çalışmada ise anlamlı ve pozitif fakat çok zayıf ve zayıf düzeyde ilişki tespit edilmiştir. Özcan vd., (2012) yapılan araştırmada, dönüşümcü liderlik ile ÖVD'nin tüm boyutları arasında anlamlı bir ilişki olduğu bulunmuş, etkileşimci liderlik ile ÖVD arasında ise anlamlı bir ilişki bulunmamıştır. Bu çalışmada ise, dönüşümcü liderlik ÖVD ilişkisi benzer sonuçlar vermekle birlikte etkileşimci liderliğin koşullu ödüllendirme boyutu ile ÖVD arasında sivil erdem boyutu dışındaki boyutların anlamlı ve pozitif ilişkisi olduğunun tespit edilmesi ile Özcan vd., (2012)'nin bulgularından farklı sonuçlara ulaşılmıştır. Oğuz (2011)'un 204 ilköğretim öğretmeni üzerinde yaptığı araştırmada, öğretmenlerin örgütsel vatandaşlık davranışları ile yöneticilerin sahip olduğu dönüşümcü liderlik ( $\mathrm{r}=.387$, $\mathrm{p}<.005)$ ve etkileşimci liderlik $(\mathrm{r}=.320, \mathrm{p}<.005)$ tarzları arasında zayıf düzeyde pozitif yönlü anlamlı bir ilişki olduğu tespit edilmiş olup, bu çalışmada ile özel eğitim sektöründe de benzer sonuçlara ulaşılmıştır.

Araştırma bulguları değerlendirildiğinde, yöneticinin uyguladığı dönüşümcü liderlik ve etkileşimci liderliğin koşullu ödüllendirme davranışları kapsamında çalışanlara ilham verme, ideal bir model sunma, entellektüel uyarım ve bireysel destek sağlama, ödül-performans ilişkisini doğru kurgulama, ödüllendirme vb. yetenekleri kapsamında çalışanların daha fazla ÖVD sergilemesine katkı sağladığ1 görülmektedir. Öğretmenler üzerinde yapılan araştırmada elde edilen bulgulara göre;

a. Dönüşümcü liderlik ile ÖVD (Genel) ve tüm boyutları arasında anlamlı ve pozitif ilişki bulunduğu tespit edilmiş,

b. Etkileşimci liderliğin koşullu ödüllendirme davranışı ile ÖVD’nin sivil erdem hariç ÖVD (Genel) ve dört boyutu arasında anlamlı ve pozitif ilişki bulunduğu tespit edilmiş,

c. Etkileşimci liderliğin koşullu ödüllendirme davranışı ile ÖVD’nin sivil erdem boyutu arasında anlamlı bir ilişki olduğuna ilişkin hipotez reddedilmiş, diğer hipotezlerin tamamı kabul edilmiş,

d. $\quad \mathrm{Bu}$ kapsamda, çalışanların ÖVD sergilemesi ile yöneticilerin uyguladıkları liderlik tarzı arasında anlamlı ve pozitif bir ilişki olduğu belirlenmiştir.

Sonuç olarak, dönüşümcü liderlik davranışı ile ÖVD (Genel) arasındaki ilişkinin ( $\mathrm{r}=.383$ ) etkileşimci liderliğin koşullu ödüllendirme davranışları ile ÖVD 
Liderlik Tarzı ile Örgütsel Vatandaşlık Davranışı İlişkisi:

Bir Özel Eğitim Kurumunda Uygulama

(Genel) arasındaki ilişkiye ( $\mathrm{r}=, 283)$ göre daha kuvvetli olduğu tespit edilmiştir. $\mathrm{Bu}$ çerçevede çalışanların ÖVD sergilemesinin artırılması için yöneticilerin dönüşümcü liderlik davranışlarına ağırlık vermesinin daha etkili olacağı değerlendirilmiştir. Liderlik tarzlarının ÖVD'nin boyutları ile ilişkisine bakıldığında ise; dönüşümcü liderliğin ÖVD'nin centilmenlik boyutu ile daha kuvvetli ilişkisinin $(\mathrm{r}=, 390)$ ve etkileşimci liderliğin koşullu ödüllendirme davranışının ise ÖVD'nin diğerkâmlık boyutu ile daha kuvvetli ilişkisinin $(r=, 450)$ olduğu tespit edilmiştir.

$\mathrm{Bu}$ çerçevede, uygulayıcılar açısından;

a. Çalışanların ÖVD kapsamındaki centilmenlik davranışlarını artırmak için dönüşümcü liderlik davranışlarına, diğerkâmlık davranışlarını artırmak için ise etkileşimci liderliğin koşullu ödüllendirme davranışlarına,

b. Genel olarak çalışanların ÖVD davranışlarını artırmak için ise dönüşümcü liderlik davranışlarına ağırlık verilmesinin uygun olacağı değerlendirilmektedir.

Bundan sonraki araştırmalarda;

a. Çalışanların ÖVD'si (Genel) ve boyutları ile yöneticinin ELKÖ'sü ilişkisinin neden DL'si ile ilişkisine göre daha zayıf olduğunun,

b. Yöneticinin ELKÖ'sü ile çalışanların ÖVD'si (Genel) ve dört boyutu arasında anlamlı ve pozitif ilişkisi olmasına rağmen, neden ÖVDSE boyutu arasında anlamlı bir ilişki olmadığının nitel çalışma yöntemi ile incelenmesinin uygun olacağı değerlendirilmektedir.

\section{Extended Summary}

\section{Introduction}

Within the framework of effective and efficient operation of the organization; without formal role definition and not directly involved in the official award system the organizational citizenship behavior (OCB) is defined as voluntary behavior that contributes to the realization of organizational goals gained importance in ensuring and sustaining organizational success (Organ, 1988). Organizational Citizenship Behavior is the most commonly used classification in 
the five-dimensional classification (gentility, gentility, conscientiousness, courtesy and civil virtue) literature determined by Organ (1988) (Özdevecioğlu, 2003).

When we examine the relationship of employees with each other and their managers in the framework of social shopping theory, it is evaluated that behaviors outside of formal role behaviors can be explained in terms of rewards and costs within the framework of reciprocity principle.(Ritzer, 1996). Within the context of social shopping theory, it is estimated that the leadership style of the manager can be the basis for the study of organizational citizenship behavior within the context of social shopping associations. Transformer and activist leadership behaviors play an important role in explaining organizational citizenship behavior.

The leadership behaviors that employees perceive as show interest, support behaviors, reward themselves, provide intellectual stimulation, participant and encouragement are expected to motivate employees to fulfill the responsibilities required for the job as well as to show the extra effort required for the success of the organization and beyond the job description. The leadership style of the manager emerges as an important precursor in the display of the employee's organizational citizenship behavior and it is seen in the research results that there is a relation between these two variables (Çakar ve Arbak, 2003). By knowing the relationship of manager's leadership style with organizational citizenship behavior, it is evaluated that managers can contribute to executives to what kind of leadership practices they should focus on.

In this study, it is aimed that the leadership style of the manager as a whole and the relation of the conditional rewarding behaviors of the transformational leadership and the activist leadership to the organizational citizenship behavior are aimed to show which leadership style has a higher contribution to the exhibitions of organizational citizenship behavior. In this context, it is evaluated that the research will be beneficial both in practice and in the contribution to the literature by testing this relationship in a special education institution in the education sector. 
Liderlik Tarzı ile Örgütsel Vatandaşlık Davranışı İlişkisi:

Bir Özel Eğitim Kurumunda Uygulama

\section{Theoretical Framework}

\section{Organizational Citizenship Behavior}

In order to be able to successfully carry out the activities of the organization under intense competition conditions, employees are expected to demonstrate extra role behaviors voluntarily within the context of organizational citizenship behavior (OCB), to help their colleagues, to comply with organizational regulations, to adopt, approve and support organizational goals (Borman, 2004). Organ (1988) defines OCB is arbitrary behavior that does not directly relate to the formal reward system but contributes to the realization of organizational goals, other than the formal roles specified in job descriptions.

Organ (1988), defines OCB as altruism, sportmenship, courtesy, conscientiousness and civic virtue. In the researches on OCB, focusing on the precursors of these behaviors, Podsakoff et al. (2000) defines as individual characteristics, organizational characteristics, task characteristics and leadership practices.

\section{Leadership}

As a collective living social entity, human beings must work together in the framework of social coordination and cooperation to fulfill their differentiated needs. Leadership in this framework is the process of directing the behaviors of followers to achieve common goals and the relationship between the leader and the followers (Şimşek, 1998). Due to the fact that different leadership styles have different effects on followers, the relationship between the applied leadership style and the OCB is particularly prominent. In cases where the manager shares information, interactives, is participatory and supportive management, employees are more likely to exhibit desirable behaviors. In addition to that, it has been found that these behaviors increase the manager-employee, employee-employee solidarity and organizational performance (Altuntaş ve Baykal, 2010). 


\section{Method}

\section{Sample}

The universe of the study was identified as 470 teachers working in 11 schools of a private education institution at Istanbul Province Anatolian Side. Distributes 370 surveys were filled by 295 named subjects.

\section{Instruments}

In this study an 18 item scale namely OCB is utilized by using two separate studies of Vey and Campbell (2004) and Williams and Shiaw (1999). As the scale of leadership style; A 36-item leadership style scale, translated into Turkish by Yurtkoru (2001), tested for validity and reliability, used by researchers and adapted from Bass and Avolio (2000) Multi-factor Leadership Questionnaire, was used.

\section{Analyze and Findings}

Analysis of collected data was done with SPSS and Amos programs. Reliability analyzes were performed using the Cronbach Alpha reliability coefficient. Validity analysis was done by exploratory and confirmatory factor analysis. The evaluation of the proposals in the questionnaire was made on a Likert scale of 5.

There was a very weak positive correlation between transformational leadership and OCB (altruism) $(\mathrm{r}=, 197 ; \mathrm{p}=, 001<, 05)$. There was a very weak positive correlation between transformational leadership and OCB (conscientious) $(\mathrm{r}=, 229 ; \mathrm{p}=, 000<, 05)$. There was a very weak positive correlation between transformational leadership and OCB (courtesy) $(r=, 231 ; \mathrm{p}=, 000<, 05)$. There was a weak positive correlation between transformational leadership and OCB (sportsmanship) $(\mathrm{r}=, 39 ; \mathrm{p}=, 000<, 05)$. There was a very weak positive correlation between transformational leadership and OCB (civic virtue) $(r=, 25 ; \mathrm{p}=, 000<, 05)$. There was a weak positive correlation between transformational leadership and OCB (overall) $(\mathrm{r}=, 383 ; \mathrm{p}=, 000<, 05)$. 
Liderlik Tarzı ile Örgütsel Vatandaşlık Davranışı İlişkisi:

Bir Özel Eğitim Kurumunda Uygulama

There was a weak positive correlation between transactional leadership conditional rewarding and OCB (altruism) $(\mathrm{r}=, 450 ; \mathrm{p}=, 000<, 05)$. There was a weak positive correlation between transactional leadership conditional rewarding and OCB (conscientious) $(\mathrm{r}=, 152 ; \mathrm{p}=, 009<, 05)$. There was a weak positive correlation between transactional leadership conditional rewarding and OCB (courtesy) $(\mathrm{r}=, 182 ; \mathrm{p}=, 002<, 05)$. There was a weak positive correlation between transactional leadership conditional rewarding and OCB (sportsmanship) $(\mathrm{r}=, 175 ; \mathrm{p}=, 003<, 05)$. There was a positive correlation between transactional leadership conditional rewarding and OCB (overall) $(\mathrm{r}=, 283 ; \mathrm{p}=, 000<, 05)$. There was no significant relationship between transactional leadership conditional rewarding and OCB (civic virtue) $(\mathrm{p}=, 178>, 05)$.

\section{Discussion and Conclusion}

Within the scope of the investigation of the interrelationships between variables, the study was considered as a dependent variable. Among the forerunners of the OCB is the determination of the relationship of the transformational leadership and the interactivity leadership style to the conditional awarding dimension. As a result, it has been found that the relationship between leadership style and OCB is very weak and weak (between $r=152$ and $r=450$ ). It was found that the relationship between the transformationist leadership behaviors and OCB (overall) is more strong than the relationship between the conditional reward behaviors of the leader leadership $(\mathrm{r}=.383)$ and OCB (overall) $(\mathrm{r}=$, 283). It has been evaluated that it will be more effective for executives to focus on the transformationist leadership behaviors in order to increase the OCB exhibition in this framework. When we look at the relation of leadership styles to the dimensions of the OCB; it was found that the leader of the transformer was more strongly related to the gender dimension of the OCB $(\mathrm{r}=, 390)$ and the conditional rewarding behavior of the interaction leader was more strongly related to the OCB than the other dimension $(r=450)$. It was evaluated that it would be appropriate to focus on the transformationist leadership behaviors in order to increase the gentlemanly behaviors of the employees and the conditional rewarding behaviors 
of the activist leadership in order to increase other personality behaviors under the OCB.

In the following investigations; Although there is a meaningful and positive relationship between the conditional rewarding behavior of the manager's activist leadership and the employees' OCB (overall) and the four dimensions, it is thought to be useful to examine qualitatively that there is no meaningful relationship between the dimension of the civic virtue of the OCB.

\section{Kaynakça}

\section{Kitaplar}

Bayram, N. (2010). Yapısal Eşitlik Modellemesine Giriş, Ekin Kitabevi, Bursa.

Bryne, B. M. (2001), Structural equation modeling with AMOS, Lawrence Erlbaum Associates, NJ.

Burns, J.M. (1978). Leadership, Harper and Row, New York.

Büyüköztürk, Ş. (2016). Sosyal Bilimler İçin Veri Analizi El Kitabı, Pegem Akademi, Ankara.

Coşkun, R., Altunışık, R., Bayraktaroğlu, S. ve Yıldırım, E. (2015). Sosyal Bilimlerde Araştırma Yöntemleri, Sakarya Kitabevi, Sakarya.

Kalaycı, Ş. (2006). "SPSS Uygulamalı Çok Değişkenli İstatistik Teknikleri”, Asil Yayın Dağıtım, Ankara.

Karasar, N. (2005). Bilimsel Araştırma Yöntemi, Nobel Yayın Dağıtım, Ankara.

Katz, D., ve Kahn, R. L. (1966). The Social Psychology of Organizations, John Wiley, New York.

Koçel, T., (2013). Işsletme Yöneticiliği, Beta Yayınları, İstanbul.

Meydan, C.H. ve Şeşen, H. (2015). Yapısal Eşitlik Modellemesi AMOS Uygulamalar, Detay Yayınc1lı, Ankara.

Organ, D.W. (1988). Organizational Citizenship Behavior: The Good Soldier Syndrome, Lexington Books, Lexington, MA.

Özdamar, K. (2002), Paket Programlar İle İstatiksel Veri Analizi, Kaan Kitabevi, Eskişehir. 
Liderlik Tarzı ile Örgütsel Vatandaşlık Davranışı İlişkisi:

Bir Özel Eğitim Kurumunda Uygulama

Özler, N.D.E. (2015). Örgütsel Davranışta Güncel Konular, Ekin Basın Yayın Dağıtım, Bursa.

Ritzer, G. (1996). Modern Sociological Theory, McGraw-Hill Education, London, UK.

Roach, C.F. ve Behling, O. (1984). "Leaders and Managers: International Perspectives on Managerial Behavior and Leadership", Pergamon Press, NY.

Sabuncuoğlu, Z. ve Tüz, M. (2008). Örgütsel Psikoloji, Alfa Basım Yayım, Bursa.

Schein, E.H. (1985). Organizational Culture and Leadership,: John WileySons Inc., San Francisco.

Şimşek, M.Ş. (1998). Yönetim ve Organizasyon, Damla Matbaacılık, Konya.

Yukl, G. (2010). Leadership in Organizations, Pearson Prentice Hall Inc: USA.

\section{Makaleler}

Acar, A.Z. (2006). "Örgütsel Vatandaşlık Davranış1: Kavramsal Gelişimi ile Kişisel ve Örgütsel Etkileri”, Doğuş Üniversitesi Dergisi, C: 7, No: $\quad 1$, ss. 1-14.

Altuntaş, S. ve Baykal, Ü. (2010). "Örgütsel Vatandaşlık Düzeyi Ölçeğinin Hemşirelikte Geçerlik-Güvenilirliği”, Anadolu Hemşirelik ve Sağllk Bilimleri Dergisi, C: 13, No: 3, ss. 7-16.

Arslantaş, C. ve Pekdemir, I. (2007). "Dönüşümcü Liderlik, Örgütsel Vatandaşlık Davranışı ve Örgütsel Adalet Arasındaki İlişkileri Belirlemeye Yönelik Görgül Bir Araştırma”, Anadolu Üniversitesi Sosyal Bilimler Dergisi, C: 7, No: 1, ss. 261-286.

Aslan, Ş. (2008). "Örgütsel Vatandaşlık Davranış1 ile Örgütsel Bağl1lık ve Mesleğe Bağlılık Arasındaki İlişkilerin Araştırılması", Yönetim ve Ekonomi, C :15, No: 2, ss. 163-178.

Avc1, A. (2015). "Örgütsel Vatandaşlık Davranışları: Kavramsal Gelişimi ve Eğitim Örgütleri Açısından Etkileri”, Hasan Ali Yücel Eğitim Fakültesi Dergisi, C:12, No: 24, ss. 11-26. 
Avolio, B.J., Bass, B.M. ve Jung, D.I. (1999). "Re-examining the Components of Transformational and Transactional Leadership Using the Multifactor Leadership Questionnaire", Journal of Occupational Organizational Psychology, C: 72, No: 4, ss. 441-462.

Avolio, B.J. ve Bass, B.M. (2002). Developing Potential Across a Full Range of Leadership Cases on Transactional and Transformational Leadership, Lawrence Erlbaum Associates, Mahwah, N.J.

Bağc1, Z. (2014). "Duygusal Zeka ve Örgütsel Vatandaşlik İlişkisi”, Hitit Üniversitesi Sosyal Bilimler Enstitüsü Dergisi, No: 2, ss. 259-279.

Basım, N.H. ve Şeşen, H. (2006). "Otel Çalışanları Açısından Duygusal Zekanın Örgütsel Vatandaşlık Davranışı Üzerindeki Etkisi”, Ankara Üniversitesi SBF Dergisi, C: 61, No: 4,ss. 83-101.

Borman, W.C. (2004). "The Concept of Organizational Citizenship", American Psychological Society, C: 13, No: 6, ss. 238-241.

Çakar, U. ve Arbak, Y. (2003). "Dönüşümcü Liderlik Duygusal Zeka Gerektirir mi?: Yöneticiler Üzerinde Örnek Bir Çalışma”, D.E.Ü.İI.B.F. Dergisi, C: 2, ss. 83-98.

Demir, C., Yılmaz, K. ve Çevirgen, A. (2010). "Liderlik Yaklaşımları ve Liderlik Tarzlarına İlişkin Bir Araştırma”, Alanya İşletme Fakültesi Dergisi, C: 2, No: 1, ss. 129-152.

Demir, H. ve Okan, T. (2008). "Etkileşimsel ve Dönüşümsel Liderlik: Bir Ölçek Geliştirme Denemesi”, Yönetim, No: 61, ss. 72-90.

Drath, W.H. ve Palus, C.J. (1994). "Making common sense: Leadership as Meaning-Making in a Community of Practice", Center for Creative Leadership, Greensboro, NC.

Finkelstin, M. ve Penner, A.L. (2004). "Predicting Organizational Citizenship Behavior: Integrating the Functional and Role Identity Approaches", Social Behavior and Personality, C: 32, No: 4, ss. 383-398.

George, M.J. ve Brief, P.A. (1992). "Feeling Goog-Doing Good: A Conceptual Anlysis of the Mood at Work-Organizational Spontaneity Relationship", Psychological Bulletin, C: 112, No: 2, ss. 310-329. 
Liderlik Tarzı ile Örgütsel Vatandaşlık Davranışı İlişkisi:

Bir Özel Eğitim Kurumunda Uygulama

Gouldner, A.W. (1960). "The Norm Of Reciprocity: A Preliminary Statement", American Sociological Review, No: 25, ss. 161-178.

Gürbüz, S. (2006). "Örgütsel Vatandaşlık Davranışı ve Duygusal Bağl1lık Arasındaki İlişkilerin Belirlenmesine Yönelik bir Araştırma”, Ekonomik ve Sosyal Araştırmalar Dergisi, C: 3, No: 1, ss. 48-75.

Hemphill, J.K. ve Coons, A.E. (1957). "Development of the Leader Behavior Description Questionnaire (R. M. Stodgill and A. E. Coons), Leader Behavior: Its Description and Measurement." Columbus, Ohio: Bureau of Business Research, Ohio State University, ss. 6-38.

Ilie, M.P. (2014). "Organizational Citizenship Behavior, Work Satisfaction and Employees' Personality", Procedia-Social and Behavioral Sciences, No. 127 , ss. 489-493.

İşbaşı, J.Ö. (2000). "Örgütsel Vatandaşlık Davranış1: Farklı Ölçeklerin Uygulanabilirliğine İlişkin Bir Çalışma", 8 nci Ulusal Yönetim ve Organizasyon Kongresi, ss. 359-372.

İşcan, F.Ö. (2006). "Dönüştürücü / Etkileşimci Liderlik Algısı ve Örgütsel Özdeşleşme İlişkisinde Bireysel Farklılıkların Rolü”, Akdeniz Üniversitesi İ.I.B.F. Dergisi, C: 6, No: 11, ss. 160-177.

Karaaslan, A., Özler, D.E. ve Kulaklığlu, A.S. (2009). "Örgütsel Vatandaşlık Davranışı ve Bilgi Paylaşımı Arasındaki İlişkiye Yönelik Bir Araştırma", Afyon Kocatepe Üniversitesi İIBF Dergisi, C: 11, No: 2, ss. 135-160.

Katz, D. (1964). “The Motivational Basis of Organizational Behavior”, Behavioral Science, No. 9, ss. 131-133.

Keleş, Y. ve Pelit, E. (2009). "Otel İşletmesi İşgörenlerinin Örgütsel Vatandaşlık Davranışları: İstanbul'daki Beş Yıldızlı Otel İşletmelerinde Bir Araştırma”, Ekonomik ve Sosyal Araştırmalar Dergisi, C: 5, No: 2, ss. 24-45.

MacKenzie, S.B., Podsakoff, P.M. ve Fetter, R. (1991). "Organizational Citizenship Behavior and Objective Productivity as Determinants of Managerial Evaluations of Salespersons' Performance", Organizational Behavior and Human Decision Processes, No: 50, ss. 123-150. 
Morçin, S.E. ve Morçin, İ. (2013). "Etkileşimci Liderliğin Örgütsel Vatandaşlık Davranışına Etkisi: Adana'daki Seyahat Acenteleri Örneği”, Süleymen Demirel Üniversitesi Vizyoner Dergisi, C: 4, No: 9, ss. 70-80.

Morrison, E.W. (1994). "Role Definitions and Organizational Citizenship Behavior: The Importance of the Employee's Perspective", Academy of Management Journal, C: 37, No: 6, ss. 1543-1567.

Oğuz, E. (2011). "Öğretmenlerin Örgütsel Vatandaşlık Davranışları ile Yöneticilerin Liderlik Stilleri Arasındaki İlişki”, Kuram ve Uygulamada Eğitim Yönetimi, C: 17, No: 3, ss. 377-403.

Organ, D.W. ve Ryan, K. (1995). "A Meta-Analytic Review of Attitudinal and Dispositional Predictors of Organizational Citizenship Behavior", Personnel Pshchology, No: 48, ss. 775-802.

Organ, D.W., Podsakoff, P.M. ve Mackenzie, S.B. (2006). Organizational Citizenship Behavior: Its Nature, Antecendents and Concequences, Sage Publications.

Özcan, E.D., Vardarlıer, P., Karabay, M.E., Konakay, G. ve Çetin, C. (2012).

"Liderliğin Örgütsel Vatandaşlık Davranışı ve İşten Ayrılma Niyeti Üzerindeki Etkisinde Güvenin Rolü”, Öneri, C: 10, No: 37, ss. 1-13.

Özdevecioğlu, M. (2003). "Örgütsel Vatandaşlık Davranışı ile Üniversite Öğrencilerinin Bazı Demografik Özellikleri ve Akademeik Başarıları Arasındaki İlişkilerin Belirlenmesine Yönelik Bir Araştırma”, Erciyes Üniversitesi İktisadi ve İdari Bilimler Fakültesi Dergisi, No: 20, ss. 117-135.

Podsakoff, P.M., MacKenzie, S.B., Moorman, R.H. ve Fetter, R. (1990). "Transformational Leader Behaviors And Their Effects On Followers' Trust in Leader, Satisfaction and Organizational Citizenship Behaviors", Leadership Quarterly, No: 1, ss. 107-142.

Podsakoff, P.M., Mackenzie, S.B., ve Bommer, W.H. (1996). "Transformational Leader Behaviors and Subtitutes for Leadership as Determinants of Employee Satisfaction, Commitment, Trust and Organizational Citizenship Behaviors", Journal of Management, No: 22, ss. 259-298.

Podsakoff, P.M., Mackenzie, S.B., Paine, J.B. ve Bachrach, D.G. (2000). "Organizational Citizenship Behaviors: A Critical Review Of The 
Liderlik Tarzı ile Örgütsel Vatandaşlık Davranışı İlişkisi:

Bir Özel Eğitim Kurumunda Uygulama

Theoretical and Empirical Literature and Suggestions For Future Research", Journal of Management, C: 26, No: 3, ss. 513-563.

Ryan, J. (2001). "Moral Reasoning As a Determinant of Organizational Citizenship Behaviors: A Study in the Public Accounting Profession”, Journal Of Bussiness Ethics, No: 33, ss. 233-234.

Schnake, M. (1991). "Organizational Citizenship A Review, Proposed Model and Research Agenda", Human Relations, C: 44, No: 7, ss. 735-759.

Schnake, M.E. ve Dumler, M.P. (2003). "Levels of Measurement and Analysis Issues in Organizational Citizenship Behavior Research", Journal of Occupational and Organizational Psychology, C: 76, No: 3, ss. 283-301.

Sezgin, F. (2005)." Örgütsel Vatandaşlık Davranışları: Kavramsal bir Çözümleme ve Okul Açısından Bazı Çıkarımlar”, Gazi Eğitim Fakültesi Dergisi, C: 25, No: 1, ss. 317-339.

Smircich L. ve Morgon, G. (1982). "Leadership: The Management of Meaning", Journal of Applied Behavioral Science, C: 18, No: 3, ss. 257-273.

Smith, C.A., Organ, D.W., ve Near, J.P., (1983). "Organizational Citizenship Behavior: Its Nature and Antecedents", Journal of Applied Psychology, No: 68, ss. 653-663.

Van Dyne, L., Graham, W.J. ve Dienesch, M.R. (1994). "Organizational Citizenship Behavior: Construct Redefinition, Measurement and Validation", Academy of Management Journal, C: 37, No: 4, ss. 765802.

Vey, M.A. ve Campbell, J.P. (2004). "In-Role or Extra-Role Organization al Citizenship Behavior: Which Are We Measuring?", Human Performance, C: 17, No: 1, ss. 119-135.

Williams, S. ve Shiaw, W.T. (1999). "Mood and Organizational Citizenship Behavior: The Effects of Positive Affect on Employee OCB Intentions", The Journal of Psychology, C: 13, No: 6, ss. 656-668.

Yener, M. ve Akyol, S.E. (2009). "Girişimcilik Değerleri ve Örgütsel Vatandaşlık Davranışları Üzerine bir Araştırma”, Süleyman Demirel Üniversitesi Iktisadi ve İdari Bilimler Dergisi, C: 14, No: 1, ss. 255271. 
Yolaç, S. (2011). "Yöneticinin Algılanan Liderlik Tarzı ile Yöneticiye Duyulan Güven Arasındaki İlişkide Lider-Üye Etkileşiminin Rolü”, Öneri: Marmara Üniversitesi Sosyal Bilimler Enstitüsü Hakemli Dergisi, No: 9, ss. 63-72.

\section{Tezler}

Yurtkoru, S.E. (2001). "The Role of Leadership in the Organizational Change Process", Doktora Tezi, Marmara Üniversitesi Sosyal Bilimler Enstitüsü. Kulaklığlu, A.S. (2009). "Örgütsel Vatandaşlık Davranışı ve Bilgi Paylaşımı İlişkisi: Bir Uygulama", Dumlupınar Üniversitesi Sosyal Bilimler Enstitüsü, Yüksek Lisans Tezi, Kütahya.

\section{İnternet Kaynakları}

Bass, B.M. ve Avolio, B.J. (2000). "MLQ 5X Scale Item Number \& Content", (Çevrimiçi), http://www.cls.binghampton.edu/mlq.html, 18 Nisan 2015.

Richards, D. ve Engle, S. (1986). "After the Vision: Suggestions to Corporate Visionaries and Vision Chapmions", (Çevrimiçi), www.buseco.monash.edu/mgt/research/working-papers, 24 Ekim 2015. 